Article

\title{
Social Impact of Value-Based Banking: Best Practises and a Continuity Framework
}

\author{
Adriana Kocornik-Mina ${ }^{1, *}$, Ramon Bastida-Vialcanet ${ }^{2} \mathbb{D}$ and Marcos Eguiguren Huerta ${ }^{3}$ \\ 1 Metrics and Research, Global Alliance for Banking on Values, 1092AD Amsterdam, The Netherlands \\ 2 Department of Finance, Accounting and Control, UPF-Barcelona School of Management, 08008 Barcelona, \\ Spain; ramon.bastida@upf.edu \\ 3 UPF-Barcelona School of Management, 08008 Barcelona, Spain; marcos.eguiguren@bsm.upf.edu \\ * Correspondence: adriana.kocornik@gabv.org
}

\section{check for}

updates

Citation: Kocornik-Mina, A.; Bastida-Vialcanet, R.; Eguiguren Huerta, M. Social Impact of Value-Based Banking: Best Practises and a Continuity Framework. Sustainability 2021, 13, 7681. https://doi.org/10.3390/ su13147681

Academic Editors: Maria Del Mar Miralles-Quirós and José Luis Miralles-Quirós

Received: 20 May 2021

Accepted: 2 July 2021

Published: 9 July 2021

Publisher's Note: MDPI stays neutral with regard to jurisdictional claims in published maps and institutional affiliations.

Copyright: (c) 2021 by the authors. Licensee MDPI, Basel, Switzerland. This article is an open access article distributed under the terms and conditions of the Creative Commons Attribution (CC BY) license (https:// creativecommons.org/licenses/by/ $4.0 /)$.

\begin{abstract}
How do financial institutions enable social impact? We examined this question in the context of values-based financial institutions, which are amongst the most experienced institutions around the world in addressing the very real banking needs of enterprises and individuals within their communities. There is, indeed, an urgency today to have the banking industry consider its social impact in a holistic way. This paper expands our understanding of how these financial institutions, all members of the Global Alliance for Banking on Values, define, design, implement, monitor and scale-up social impact. We used a multiple-case studies design to investigate their approach and inductive analysis to derive a model. From a theoretical perspective, we found that a social impact virtuous circular model best reflects how values-based financial institutions approach and practise social impact. Each step of the circular model clearly shows the way in which these institutions address and achieve social impact. Our findings have important implications for academic research focussed on understanding how finance can generate social impact. The findings of this article can, especially, also have practical implications for all types of financial institutions willing to improve the way in which they address social challenges and, ultimately, increase their social impact. At a time when more resources are needed to meet the Sustainable Development Goals, this is urgent.
\end{abstract}

Keywords: social impact; values-based banking; sustainable banking; sustainable finance; global banking best practises; SDGs; best practises; ethical banking; ESG

\section{Introduction}

The UN Sustainable Development Goals (SDGs) provide a blueprint to address global challenges to be achieved by 2030 [1]. Until now, progress has been both insufficient and uneven [2-5]. Amongst the most commonly cited reasons for poor performance across this global framework are (a) funding gaps [6], particularly in developing countries [7]; (b) the recognition of the limits of shareholder wealth maximisation [8] and the criticism of the view that 'a corporation's only social responsibility is to increase profits' [9]; (c) the relationship between finance and sustainability [10-12] viewed by some as inadequate to finance the SDGs $[13,14]$.

The 2030 Agenda for Sustainable Development explicitly called for the promotion of Social Inclusion. The United Nations [15] defines social inclusion as "the process of improving the terms of participation in society for people who are disadvantaged on the basis of age, sex, disability, race, ethnicity, origin, religion, or economic or other status, through enhanced opportunities, access to resources, voice and respect for rights.

In that sense, SDG 16 calls for inclusive societies, institutions and decision making, and SDG 10 encourages social, economic and political inclusion in order to reduce inequalities amongst countries. SDG 8 and SDG 9 point out the need for inclusive growth and industrialisation and SDG 4 for an inclusive approach to quality education [16]. 
Studies reveal that there exists a positive and significant correlation between social inclusion and financial inclusion, which is the process of ensuring all individuals have access to basic financial services through their participation in the formal financial sector [17]. Therefore, increasing the financial inclusion of individuals would contribute to sustainable development and the achievement of the SDGs.

Already, in the Millennium Development Goals (MDGs), launched by the UN before the Sustainable Development Goals, financial inclusion was viewed as an important means to tackle poverty and achieve sustainable growth. Findings from a research field developed by Chibba [18] concluded that financial and non-financial private sector development, financial literacy, microfinance and public sector support were four fundamental pillars needed to scale-up financial inclusion, alleviate poverty and achieve the MDGs.

Kandpal [19] also pointed out the important role of a well-equipped financial system in achieving sustainable growth, economic development and progress of an economy at a country level. In that sense, there is clear evidence that financial inclusion and SDGs are interlinked; therefore, it is important that governments make efforts to include as many people as possible in the financial system [20,21].

In this context, sustainable finance is evolving and a new paradigm of finance is emerging [22]. For its novelty, literature linking sustainable finance and SDGs is still scarce, although some studies reveal a linkage between both concepts [23]. Ziolo et al. [24] analysed the link between a sustainable finance model and the achievement of the SDGs. The findings verify the main hypothesis of their link indicating that the more sustainable the finance model, the better the results of a given country in achieving SDGs.

Moreover, the financial sector is changing its approach to impact from not considering non-financial impacts to increasingly seeking to understand and manage these. In that sense, more banks are implementing active policies to avoid negative impacts and to generate positive impacts [25]; the importance for financial resilience of embedding sustainability is also becoming more evident [26,27].

SDGs are about achieving a series of positive impacts and avoiding a set of negative ones. SDGs invite the fulfilment of people's needs (i.e., the social dimension), within the physical boundaries of our planet (i.e., the environmental dimension), recognising that businesses and jobs are key to achieving this (i.e., the economic dimension). Therefore, the journey of finance towards positive impact and the achievement of the SDGs is completely aligned. Sustainable banks can enhance their positive impact helping to achieve the SDGs' goals.

The pursuit of positive impact is being conducted in different ways:

1. One approach is via principles, taxonomies and certification systems. A number of frameworks have been developed to mobilise financial resources to generate positive impact and achieve the SDGs' goals. The principles for positive impact finance are a common framework to finance the SDGs set by the United Nations Environment Programme Finance Initiative (UNEP FI) [28]. In June 2019, the European Union (EU) published the Sustainable Finance Taxonomy [29]. Moreover, in June 2020, the United Nations Development Programme (UNDP), China and the China International Center for Economic and Technical Exchanges (CICETE) think tank, published the UNDP SDG Finance Taxonomy aiming to address this missing link between SDGs and financing [30];

2. A second approach is via reporting frameworks. Currently, reporting frameworks like the Global Reporting Initiative (GRI) and the International Integrated Reporting Council (IIRC) are working to align with the SDGs as are newer initiatives such as the World Benchmarking Alliance (WBA) and the Impact Management Project (IMP). The Global Impact Investing Network (GIIN) hosts IRIS+, a catalogue of generally accepted performance metrics that help investors measure and manage impact;

3. A third approach is providing instruments to assess and manage impact within sustainable banks. In that sense, the Global Alliance for Banking on Values (GABV) has developed a Scorecard based on GABV's Principles of Values-Based Banking [31]. 
It allows a bank to self-assess, monitor and communicate its progress on delivering value to society.

The aim of this paper was twofold. First, to shed light on understanding how impactful banks manage to define, design, implement, monitor and scale-up impact. Their vast experience is a valuable resource during these urgent times. Second, to analyse value-based banking best practises to achieve social impact. The analysis was based on a sample of impact frontrunners banks that are members of the GABV.

The contributions of this paper are also two-fold. Firstly, it broadens the scarce literature on social impact assessment in finance through an in-depth analysis of best practises carried out by frontrunners in values-based banking. This study presents a unique systematic approach of the best practises linked to defining, designing, implementing, monitoring and scaling-up of 30 financial institutions, all members of the GABV. Secondly, the findings of this paper might help practitioners (bank managers, investors, public authorities, etc.) design effective social impact frameworks and practises.

The remainder of this manuscript is organized as follows. Section 2 presents the literature review regarding social impact practises. Once this is analysed, the theoretical framework is also considered. Section 3 includes the methodology and data collection and analysis. In Section 4, the results are presented. Discussion of the findings and concluding remarks are put forward in Sections 5 and 6.

\section{Literature Review}

A review of the literature reveals research projects that consider sustainable banks as banks that have made responsibility for the environment and society the core of their business and mission. The evolution of sustainable banking began when banks held themselves accountable to society and concepts, such as ethical banking and corporate social responsibility (CSR), emerged [32].

\subsection{Practises of Value-Based Banking}

The literature review allows us to identify existing practises in the sustainable banking industry. A closer look at these practises suggests these can be grouped into (1) those related to the stage of understanding and definition of social impact; (2) those that correspond to the design stage; (3) those corresponding to the implementation stage; finally, (4) the practises related to monitoring processes.

\subsubsection{Practises Related to the Understanding and Definition of Social Impact}

The lack of consensus on the definition of social impact causes confusion and hampers the ability to study the phenomenon. Variations are found among various academic fields such as business and society studies, management accounting and strategic management. Moreover, the term social impact is often replaced by terms such as social value creation [33] and social return [34]. An overview of a number of definitions can be found in Maas et al. [35].

Burdge and Vanclay [36] defined social impact as the consequences to human populations of any public or private action that alter the ways in which people live, work, play, relate to one another, organise to meet and, generally, act as members of society. Gentile [37] referred to social impacts as the wider societal concerns that reflect and respect the complex interdependence between business practise and society. In addition, more recently, social impact has been defined as the intended and unintended social consequences, both positive and negative, of planned interventions (e.g., policies, programmes, plans and projects) and any social change processes invoked by those interventions [38].

Regarding the literature, social impact is a rather new concept which still needs further development. However, in the previous definitions, there are already some common trends that characterise this concept. Firstly, they agree that social impact is the effect in society of either public or private initiatives or activities. Thus, it recognises the externalities that 
certain activities have in the population. Secondly, they also agree that these effects can be positive or negative depending on the outcomes of the activities developed in the society.

In October 2015, UNEP FI released the Positive Impact Manifesto [39] calling for a new finance paradigm. The development of a dedicated set of Principles for Positive Impact Finance to guide financiers and investors in their efforts to increase their positive impact on the economy, society and the environment, constitutes a central component of the Manifesto. In that sense, Principle One defines positive impact as that which serves:

a. To finance positive impact businesses;

b. To deliver a positive contribution to one or more of the three pillars of sustainable development (i.e., economic, environmental and social), once any potential negative impacts to any of the pillars have been duly identified and mitigated;

c. To respond to the challenge of financing the SDGs.

The Principles for Responsible Banking (PRB) set out by UNEP Finance Initiative [7] is a framework for ensuring that signatory banks' strategy and practise align with the vision society has set out for its future in the SDGs and the Paris Climate Agreement. The second principle focuses on Impact and Target Setting, and it states:

"We will continuously increase our positive impacts while reducing the negative impacts on, and managing the risks to, people and environment resulting from our activities, products and services. To this end, we will set and publish targets where we can have the most significant impacts."

According to PRB, positive impact might be embedded in activities, products and services developed by values-based financial institutions. Therefore, they might set and publish impact targets and enable the necessary resources to achieve them. In that sense, the Principles of Values-Based Banking, set out by the GABV, represent a guideline for values-based financial institutions [40]:

1. Social and environmental impact and sustainability are at the heart of the business model.

2. Grounded in communities, serving the real economy, and enabling new business models to meet the needs of people.

3. Long-term relationships with clients and a direct understanding of their economic activities and the risks involved.

4. Long-term, self-sustaining, and resilient to outside disruptions.

5. Transparent and inclusive governance.

All of these principles are embedded in the culture and leadership of the organization.

The banking sector has taken a step forward to define social impact. UNEP FI has set the basis for a more concrete characterisation of positive social impact in the finance sector. Nevertheless, there are still voices asking for more clarity in order to avoid social and green washing practises within the banking sector [41].

\subsubsection{Practises Related to the Design Stage of Social Impact}

In line with the PRBs [7], banks are required to undertake an analysis of their impact on society, the environment and the economy. In conducting their impact assessment, banks should consider the following:

a. Scope: the bank's core business areas and products/services across the main geographies that the bank operates in;

b. The scale of exposure: where the bank's core business/major activities lie in terms of industries, technologies and geographies;

c. Context and relevance: the most relevant challenges and priorities related to sustainable development in the countries/regions in which it operates;

d. The scale and salience of impact: social, economic and environmental impact resulting from the bank's activities and provision of products and services. 
The Impact Radar developed by the UNEP FI Positive Impact Initiative offers a holistic set of impact areas across the three pillars of environment, society and economy [42]. Private finance and businesses that use this tool are able to understand and manage both positive and negative impacts across various dimensions of wellbeing including inclusive and healthy economies, availability, accessibility and affordability of water, and efficiency and security of climate resources.

Non-governmental organisations are calling upon financial institutions to implement more socially and environmentally responsible lending policies. The Collevecchio Declaration on Financial Institutions and Sustainability is one example of a principle-based approach to sustainability. It is also a call to financial institutions to advocate for regulation [43].

In the literature, many examples can be found regarding responsible financial products and services [44-48]. Carè [44] conducted a study that compared six banks on the Global 100 Sustainability Companies list to identify practises that may be linked to country-specific factors. All sampled banks were engaged in green bond initiatives and as a result disclosed much more information even when providing other green or social products. Nakano and Magezi [45] conducted a randomised control trial (RCT) to examine the impact of microcredit on the adoption of technology and productivity of rice cultivation in Tanzania, while Agyemang, Ratinger and Ahado [46] investigated the drivers of performance of women-owned businesses that primarily depend on microcredit. Separately, Imeson and Sim [47] and Stankeviciene and Nikonorova [48] noted that sustainable banking creates opportunities for innovative products and services ranging from low-income housing, energy efficiency and clean production technologies to renewable energy.

Previous studies confirm that responsible products and services are designed with a focus on different impact target settings or dimensions: sector of activity, asset class, individual characteristics, etc.

\subsubsection{Practises Related to the Implementation Stage of Social Impact}

In the next paragraphs, practises implemented by members of the GABV and other social impact frontrunner banks are presented that suggest a great diversity of approaches to social impact. Yet, there is a tendency for banks to profile their sustainable banking practises and integrate environmental and social dimensions into their business strategy [49].

A comprehensive lending policy with clear positive and negative criteria is important. Triodos Bank's positive criteria, for example, include projects that combine added cultural, social and/or environmental value with financial viability and clear benefits for the wider community. Their negative criteria help exclude all projects that involve clearly defined non-sustainable products and services such as nuclear energy, environmentally hazardous substances and the weapons industry as well as non-sustainable work processes, such as intensive agricultural production, genetic engineering and breaches of fundamental labour rights $[43,50]$. A clear ethical policy in combination with local and global certifications, such as environmental impact assessments and ISO 1400, has been used by Co-op Bank to assess projects and businesses seeking finance [51].

Value-based banks' commitment to social priorities is reflected in internal practises related to corporate governance, internal operations, services and products, human resource management, advocacy, among others.

a. Corporate governance: Co-op Bank implemented several measures to ensure that the ethical policy was embedded throughout the organisation. The bank established a "Corporate Ethical Policy" that covers five key areas: human rights; international development; ecological impact; animal welfare; social enterprise. The Co-op Bank also implemented several changes at the Board level to strengthen its monetary and credit policies and ensure its alignment with its ethical standards [51];

b. Internal operations for green business transformation: Currently, banks are developing financial operations around the globe, and their impacts on society and the environment are increasingly important. Value-based banks are conscious about the 
energy used in its buildings. As a result, optimal management of energy efficiency is the top priority for reducing the carbon footprint. Banks conduct energy audits in all their offices for effective energy management. They also utilise renewable energy (i.e., solar, wind) to power their offices [51,52];

c. Green services and products offered to the customers: Bank's commitment to offer greener products and services to their customers is reflected in their daily practises. To reduce the consumption of paper, banks rely on electronic transactions and mobile banking. They also prioritize the use of bio-sourced and recycled materials to produce credit cards, leaflets, brochures, etc., and enlarge the useful life of credit cards to reduce the use of materials [43,50];

d. Human Resource Management: Triodos Bank pays special attention to the social and ethical motivation of co-workers throughout recruitment, evaluation procedures, internal training programmes and debate and exchange sessions [50];

e. Advocacy: Meanwhile at the national level, the provision of sustainable finance is capable of influencing public policy to certain extent. Value-based banks have campaigned for the introduction of such regulation and will continue to lobby for such a mandate to be applied to all large businesses [51].

\subsubsection{Practises Related to the Monitoring Stage}

If social finance is about seeking a financial and a social return, both financial return and social impact must be measured. This emphasis on measuring social impact is the second defining feature of social finance [53].

According to the PRBs, the Principles of Values-Based Banking and the Principles for Positive Impact Finance, transparency and disclosure are key. Banks should provide transparency and disclosure as follows:

- The activities, projects, programmes and/or entities financed;

- The processes they have in place to determine eligibility and to monitor and verify impacts;

- The impacts achieved by the activities, projects, programmes and/or entities financed.

From the 1990s, many methods have been developed to measure social impact. A review of the literature suggests as many as thirty quantitative social impact measurement methods (e.g., [34,54,55]). Maas et al. [35] developed a classification system according to (1) purpose: screening, monitoring, reporting and evaluation; (2) time frame: prospective, ongoing, or retrospective; (3) orientation: input- or output-oriented; (4) length of time frame: short-term or long-term; (5) perspective: individual, organisational, or community/societal; (6) measurement approach: process, impact, or monetisation.

Impact measurement and monitoring can help frontrunner institutions to validate their achieved social impact. Impact measurement in general provides accountability to depositors who have chosen ethical financial institutions [56], as well as to investors and owners. Social impact measurement in particular can help the management team inform stakeholders and contribute to a banks' credibility, as well as its attractiveness to potential new customers and investors [57].

Bonini and Emerson offer several examples of practises for measuring and monitoring social and environmental impact of banking activities of a group of frontrunners [58]. They note that Triodos Investment Management (a subsidiary of Triodos Bank) uses IRIS+ metrics to measure, track and report social and environmental performance of its funds. Ekobanken in Sweden, Merkur Bank in Denmark and GLS Bank in Germany use a storytelling approach to disseminate the impact of their lending and operations. More recently, Charity Bank developed its own impact measurement model to capture quantitative data while still continuing storytelling based on qualitative data.

The purpose of social impact indicators is to evidence the outcomes achieved by the organisation as a result of its activities. The literature on social impact indicators distinguishes between indicators identified by experts (i.e., a top-down approach) and the ones identified by community members (i.e., a bottom-up approach) [57]. 


\subsection{Theoretical Framework}

The idea of segmenting a process into the stages of definition, design, implementation and monitoring is not new (see Figure 1). In fact, such a four-stage approach lies at the core of a project life cycle that includes conceptualisation, planning, execution, monitoring and control and termination stages [59-61]. First, the initial stage of conceptualisation, refers to the time frame at which a strategic need has been recognised by top management. Second, the planning stage formalises a set of plans to accomplish the initially developed goals. Third, the execution stage is when the work of the project is performed, while ensuring a close monitoring and control for the results. Lastly, the termination stage is when the project has been completed.
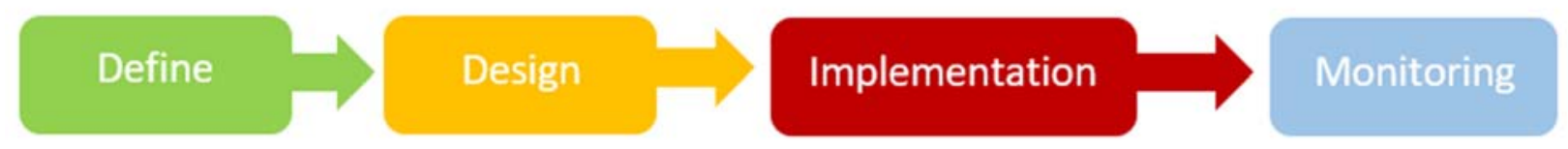

Figure 1. Stages of project management.

Such a linear approach, however, received considerable criticism from both scholars and practitioners. For example, it was highlighted that at the concept stage, the project can represent only a vague idea and is entangled by the expectations of multiple stakeholders, who try to negotiate mutually acceptable objectives.

As a response, there emerged a circular model of continuous improvement, i.e., an ongoing organisational effort to continuously improve managerial processes through learning from and analysing the firm's outputs and constantly adapting them to a changing environment [62]. Thus, a firm's output serves as a basis for organisational learning with the objective of its further improvement in order to achieve more satisfying results in the long run.

Continuous improvement appeared as a response to the ever-increasing demands of external stakeholders, mainly customers, to the attributes of the firm's outputs. In the pursuit of addressing customer needs more efficiently, firms started implementing the circular model of continuous improvement in their intra-organisational processes, as it allowed them to better adapt to what their customers expected from them. Additionally, such a circular approach allowed them to continuously learn from their customers directly, instead of relying on secondary sources, reducing the time and resources spent on innovation and minimising "waste" - a product that a customer is not willing to buy [63] This was especially useful in dynamic environments with constantly changing customer needs and expectations.

Academic research has shown that continuous improvement efforts are necessary for problem identification and rectification [64]. They also help firms to focus their key processes on creating value for customers. Moreover, they help enforce the commitment of a firm's leadership to the key organisational activities [65].

Such circular understanding seems more adequate in the context of sustainable banking, where continuous adaptation and improvement seems to be crucial for the achievement of a positive social and/or environmental impact in the communities where they operate. In this sense, a close monitoring of the results of their investment activities allows them to understand which of the financial instruments give better than expected results and how these instruments should be adapted to the dynamic environments of local communities.

The ongoing improvement of financial instruments of sustainable banking is especially important because of the differentiation between outputs and outcomes of their investments. This importance is based on the fact that measuring the outcomes of the investments allows financial institutions to assess the social impact of their investments, or the consequences of their investments on society. Meanwhile, measuring the outputs only provides information about several targets or KPIs, sometimes disconnected between them. 
The previous research on sustainable banking and continuous improvement is scarce. However, we believe that the application of a model of a continuous improvement cycle might shed additional light on how sustainable banking shapes their best practises to achieve a systemic positive social impact.

\section{Methodology}

The research design of this study was that of multiple case studies, which is especially appropriate for investigation of real-world phenomena that are too complex for surveys or experiments and that require an in-depth understanding to answer exploratory "how" and "why" questions [66].

\subsection{Data Collection}

As proposed by Patton [67], we followed a purposeful sampling technique "to select information-rich cases for study in depth". Information-rich cases are those from which one can learn a great deal of issues of central importance to the purpose of the inquiry, thus the term purposeful sampling. Studying information-rich cases yields insight and in-depth understanding rather than empirical generalisations [67].

A careful implementation of the purposeful sampling technique necessitated the implementation of two key steps. First, the choice of the Global Alliance for Banking on Values as the research setting for this study. The principle-based approach to banking for impact and sustainability is one reason to examine members of the GABV. They are also considered front runners in the field of sustainable banking, successful in translating their impact priorities into products and services [68] and embedding in the culture of their organisations the Principles of Values-Based Banking [69]. These financial institutions have consistently shown that serving the real economy, that is, the economic activities that generate goods and services as opposed to a financial economy that is concerned exclusively with activities in financial markets, delivers better and more stable financial returns than those shown by the largest banks in the world [70,71].

Second, the selection of a representative sample of 30 values-based members of the GABV for an in-depth exploration and codification of their approach to social impact (the list of institutions is provided in Appendix A). These institutions were selected based on two criteria. The first selection criterion was that we wanted a sample that included at least one-third of the population distribution in terms of business model. This criterion was applied. The second selection criterion was that we wanted at least 1 institution from each of our five regions of operation. This criterion was also applied. This global and diverse sample covers close to 50 percent of GABV members, which we consider an appropriate threshold (Table 1). More fundamentally, all GABV institutions share a commitment to the Principles of Values-Based Banking.

The development of a suitable instrument to collect information from values-based financial institutions involved two important steps. First, in line with exploratory sequential design, we collected various perspectives and approaches to social impact through an initial round of consultations with representatives of values-based financial institutions participating in the GABV's Metrics Community of Practise. Participants in this community of practise include financial officers, sustainability officers, and impact analysts. These consultations took place in November 2020.

Building on these consultations and in close collaboration with Ugo Biggeri, President of Etica Sgr and former CEO of Banca Etica, we identified a set of common building blocks of a values-based approach to social impact (see Figure 2). Finally, we developed an in-depth questionnaire and once again discussed its contents with a subset of members participating in the Metrics Community of Practise. The initial questionnaire was then pilot-tested with a handful of values-based financial institutions in January 2021. 
Table 1. Sample of GABV members.

\begin{tabular}{|c|c|c|c|c|c|}
\hline $\begin{array}{c}\text { Business } \\
\text { Model }\end{array}$ & Count* & Region & $\begin{array}{l}\text { Assets on the Balance } \\
\text { Sheet and under } \\
\text { Management (US\$ } \\
\text { Millions) }\end{array}$ & Co-Workers & Clients \\
\hline MFI & $\begin{array}{c}6 \\
(18)\end{array}$ & $\begin{array}{c}\text { Africa, Asia Pacific, } \\
\text { Europe, Latin } \\
\text { America }\end{array}$ & 4313 & 12,113 & $2,049,036$ \\
\hline OT & $\begin{array}{c}6 \\
(8)\end{array}$ & $\begin{array}{l}\text { Asia, Europe, } \\
\text { North America }\end{array}$ & 7781 & 624 & 224,245 \\
\hline $\mathrm{RB}$ & $\begin{array}{c}11 \\
(21)\end{array}$ & $\begin{array}{c}\text { Asia, Europe, Latin } \\
\text { America, North } \\
\text { America }\end{array}$ & 84,614 & 5975 & $2,730,036$ \\
\hline SL & $\begin{array}{c}7 \\
(14)\end{array}$ & $\begin{array}{l}\text { Asia, Europe, } \\
\text { North America }\end{array}$ & 41,849 & 4743 & $1,418,916$ \\
\hline Total & $\begin{array}{c}30 \\
(61)\end{array}$ & & $\begin{array}{c}138,556 \\
(169,810)\end{array}$ & $\begin{array}{c}23,455 \\
(58,207)\end{array}$ & $\begin{array}{c}6,422,233 \\
(19,188,030)\end{array}$ \\
\hline
\end{tabular}

MFI = microfinance institutions— the emerging markets model; $\mathrm{SL}=$ savings and loans— the typical credit union or cooperative model with limited or no asset management activities; $\mathrm{RB}=$ universal retail banks-besides taking private deposits, there also is a sustainable asset and wealth management branch; OT = other. Source: GABV member data. * Numbers in parentheses refer to available GABV totals by business model.

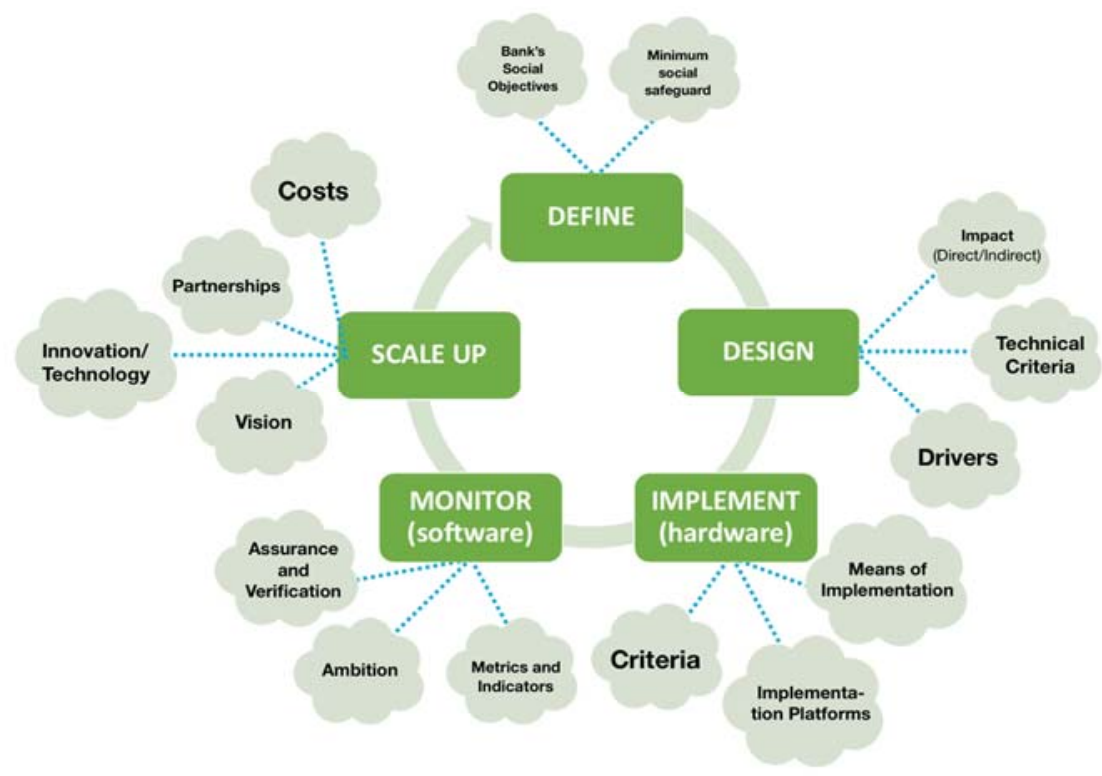

Figure 2. Building blocks of the questionnaire on social impact practises and approaches of valuesbased financial institutions.

Following an additional round of small modifications in late January/early February, the questionnaire was considered well adapted to the sample [72]. The questionnaire is provided in Appendix B. Between February and April a representative sample of values-based financial institutions submitted their responses to the questionnaire. The 30 experienced values-based co-workers who responded included two CEOs, two CROs, one Chief Impact Officer, one vice president of finance, one member of the executive board, three directors and three heads of sustainability and impact.

In-depth interviews with the CEOs of ten of the participating institutions provided additional qualitative information in support of the conclusions reached after examining the responses to the questionnaire. This subset of CEOs was purposive sampling based on 
four criteria. The first selection criterion was that we wanted to interview the person with end responsibility for the bank. The second criterion was that we wanted to have at least two interviewees from each of the three main business models used by members of the GABV. The third criterion was that we wanted to interview CEOs from as many regions as possible. The fourth criterion was that we wanted at least one interviewee who had been with the GABV since its creation in 2009, at least one who had joined midpoint and at least one who had joined in the last year or two. All criteria were applied to all interviewees (see Table 2 for the list of institutions). The CEOs shared their approach and views on scaling-up social impact. The interview protocol is provided in Appendix $C$. These interviews were conducted by Marcos Eguiguren and Ugo Biggeri between March and April 2021, each lasting between 60 and $90 \mathrm{~min}$.

Table 2. List of institutions interviewed.

\begin{tabular}{cccc}
\hline 1. & Banca Etica (Italy, 2009) & 6. & Magnet Bank (Hungary, 2016) \\
\hline 2. & $\begin{array}{c}\text { Banco Popular de Honduras } \\
\text { (Honduras, 2018) }\end{array}$ & 7. & Southern Bancorp (USA, 2015) \\
\hline 3. & Center-Invest (Russia, 2019) & 8. & Sunrise Banks (USA, 2011) \\
\hline 4. & $\begin{array}{c}\text { Dai-Ichi Kangyo Credit } \\
\text { Cooperative (Japan, 2018) }\end{array}$ & 9. & Triodos Bank (Europe, 2009) \\
\hline 5. & GLS Bank (Germany, 2009) & 10. & Vancity (Canada, 2010) \\
\hline In parentheses are the country/region of operation and year the member joined the GABV.
\end{tabular}

\subsection{Data Analysis}

In this study, mixed methods were best suited for the analysis of the collected qualitative and quantitative data [73]. This approach ensured the findings were grounded in the experience of the participants, were flexible and adaptable so more information could be collected.

Nevertheless, the collection of rich comprehensive data also poses challenges, as they are complex to plan and conduct, and integrating qualitative and quantitative data for analysis can also be challenging. A separate multi-disciplinary expert advisory committee was set-up to examine the first round of findings and highlight any potential errors. As a first effort to codify best practises for social impact, this approach was justified.

Next, we applied convergent design to compare the findings from qualitative and quantitative data sources. We separately analysed both types of data and compared the results using side-by-side comparisons. The two types of data provided validation and helped draw conclusions [72]. Ultimately, we mainly relied on an inductive approach that allowed the research findings to emerge from the raw data [74].

\section{Results}

The financial institutions that are members of the GABV practise banking guided by the above-mentioned Principles of Values-Based Banking, resulting in positive social and environmental impacts on clients and communities and profit making, not profit maximisation [75], and reflecting a focus on the interests of their stakeholders.

The model of banking articulated in the Principles of Values-Based Banking is holistic and comprehensive. It supports dual ambitions to finance change and change finance, well summarised by Triodos Bank [76]. Impact is core to these agendas and at the heart of the work of values-based financial institutions. In financing social change values-based financial institutions focus on inclusion and access to financial services for all; client awareness of the role of money in society and of deposits as a way to change the world (the liability side of the balance sheet); and on lending that enables change (the asset side of the balance sheet). In changing finance towards social sustainability and impact they rely on demonstration, education and direct advocacy. 
The approach to collecting best practises described in the methodology reflects the principled-based approach of values-based financial institutions; the data collected shows that all respondents were guided by values-informed visions of the future notwithstanding context and business models. Through their intermediation decisions, these institutions aim to bring about the kind of transformational change required to build healthy, inclusive societies that can flourish within our planetary means. As intermediaries of other people's money [77], their activities have direct, indirect, positive, negative, intended and unintended consequences [78]. The values-informed visions of the future are realised daily through clear priorities and objectives reflected in lending decisions, coherent implementation policies and processes, and proof points of progress.

The findings are presented according to the logical structure of the questionnaire in Appendix B. The practises of values-based financial institutions clarify what is required when impact is seen as the purpose of an institution. The practises also show how purposedriven financial institutions deliver.

\subsection{Practises Associated with the Definition Stage}

Impact is about the difference we make for society and the environment. This definition is related to that proposed by the Impact Institute and underpins their extensive work on impact measurement and valuation [79]. For values-based financial institutions, this difference must be positive or at least neutral, never negative. This is true for both their direct impact on clients and their indirect impact through the activities of clients. As intermediaries these values-based financial institutions have defined clear impact priorities that guide their activities and decisions. These impact priorities speak to what needs to happen to realize their vision of how a given sector or customer segment should evolve.

Amongst respondents, impact priorities are differently defined reflecting context and client needs. However, a closer look at their collected definitions of positive impact suggests there are three parts or components that are common, albeit each definition weighing their centrality differently. For a majority of respondents social and environmental impact are explicitly interlinked.

In general terms, a positive contribution to impact has three parts:

1. Values to inform decisions and the direction of travel;

2. Social, economic and/or environmental challenges that need addressing;

3. Resources in the hands of clients and communities enabled by the banking activity, i.e., jobs, health, education, basic infrastructure, housing, food and safety.

Specifically, on social impact values-based financial institutions refer to direct and indirect sustained positive effects that ameliorate social challenges and advance socially relevant values. The European pillar of social rights reflects these values [80].

\subsubsection{The "Values" Part of the Definition of Social Impact}

Values-based financial institutions have a clear set of values to inform and guide decision making, as well as engagement with clients and communities. Bank Australia's responsible banking policy translates the institution's values into offered and not offered products and services, for example [81]. In the words of one of the CEOs of a Latin American bank:"[...] defining social impact is a matter of values and culture. At our bank, helping people that are excluded from the mainstream banking system is a dream for all the coworkers".

The focus on values is a characteristic of values-based financial institutions. Specifically, the values of fairness, well-being, inclusion and affordability appear as common ambitions amongst the sample of respondents, guiding their engagements with clients and communities and informing their aspirations to enable positive transformations.

In practise, institutions that prioritise values of inclusion and fairness also report a focus on access to capital for the underprivileged and organisations for social change. Institutions that prioritise human dignity and financial freedom report a focus on quality employment, empowerment of people to save and economic resiliency. In other instances, alongside values of sustainability and well-being is a focus on directing finance to long-term 
goals for people and planet, intergenerational impact, poverty alleviation and financing of social housing projects. These are illustrative translations only of the many ways values help define and guide values-based financial institutions.

\subsubsection{The "Challenges" Part of the Definition of Social Impact}

Values-based financial institutions operate in communities that experience a variety of societal challenges; most commonly reported are growing inequality, lack of climate action, poverty and poor health and well-being.

Respondents saw offering products and services that ameliorate challenges, never worsen or create new ones as a fundamental responsibility. This may explain why a majority of respondents defined negative impact. Some definitions referred to specific activities or sectors in an institution's exclusion lists; others to roadblocks to economic freedom, e.g., reduced, limited or no access to financial services for net-worth building activities that result from geography or public policies. One of the respondents even included transactions, specifically those that may result in significant job loss or conversion of affordable rental housing into unaffordable rental units.

Values-based financial institutions recognise the intersectionality of challenges. Intersectionality is a core driver of persistent exclusion [82-85]. The concept originated as a critique of US courts' failing to recognise discrimination against black women specifically [86], but values-based financial institutions seem to understand it at a deeper level. They focus on the underrepresented and underbanked and endeavour to transform their communities by enabling fair and meaningful participation. They understand that poverty accompanied by racial discrimination is more difficult to address, and work for an inclusive and fair future starting from the design stage is examined next.

Values-based financial institutions have experience in tailoring their activities and prioritizing drivers for long-term and sustainable change. Despite different local conditions the challenges values-based financial institutions prioritise are clearly linked to their values. For example, institutions that ranked inclusion and fairness as their top two values reported growing inequality as the main challenge in their communities. Those that ranked human dignity and financial freedom as their top priorities highlighted racial and age discrimination and lack of decent work and economic growth as main challenges experienced by their community.

For values-based financial institutions, challenges represent an opportunity to innovate. The COVID-19 pandemic is a case in point. Values-based financial institutions took steps immediately to ensure continued and safe access to finance for their clients. Furthermore, they exchanged knowledge and experience developing and implementing innovative response measures consistent with their client-centredness [87].

\subsubsection{The "Resources" Part of the Definition of Social Impact}

Enabling resources-jobs, health, education, basic infrastructure, housing, food and safety-through banking products and services is a core banking activity. Of these, valuebased financial institutions report access to housing, access to education and job creation as priority resources for social impact.

According to respondents these resources impact various dimensions of well-being some more directly than others. For example, home mortgages, personal consumer lending, and financial literacy have a direct impact on a client's well-being. On the other hand, SME financing can indirectly impact the well-being of the community mainly in the following four dimensions: inclusive, healthy economies; water, air, soil, climate, biodiversity and ecosystems; energy and mobility; resource efficiency.

The dimension of resources is further developed in the following section as, it is a key design area of the social impact approach of values-based financial institutions. 


\subsection{Practises Associated with the Design Stage}

How values-based financial institutions approach the delivery of social impact is as important as the type of social impact they pursue. They rely and are confident of their impact largely because of the steps and dimensions they consider in its design.

\subsubsection{Social Impact Embedded by Design}

The most important dimension in the design approach of values-based financial institutions is to ensure that strategies, processes and actions support the delivery of social impact priorities. Embedding impact targets in product and service design, excluding harmful sectors, and designing customised indicators to measure and report progress are also important, although to a somewhat lesser extent.

The design of strategies, processes and actions is typically characterised by a holistic flow from high-level direction (i.e., the why), processes and implementation (i.e., the how), to identifiable results (i.e., the what). Impact design elements cover aspects of leadership, organisational structure, products and services, management systems, human resource tools and performance reporting. The culture and capability development are in alignment to support success.

\subsubsection{Dimensions of Impact Design}

Products and services embed impact targets in a variety of ways. The main dimensions of impact design are by economic sector (e.g., agriculture, energy, arts and culture); asset class (mortgages, commercial real estate, business loans, etc.); personal characteristics of clients (race, gender, employment status, etc.). These dimensions vary by product type.

Table 3 lists the design dimensions of products and services that deliver social impact and the percent of respondents that ranked it as most relevant. For 39 percent of respondents, client personal characteristics was the most relevant design dimension of current accounts. For microfinance and consumer loans, it was quality of life (35 percent and 24 percent, respectively), while sector was the top dimension for business loans (27 percent) and investment products (33 percent). The most relevant impact design dimension for mortgages was client type of activity ( 30 percent) and for financial advice, a service, it was quality of life (32 percent).

Table 3. The Most relevant dimensions of impact design, by product and service.

\begin{tabular}{|c|c|c|c|c|c|c|c|}
\hline & $\begin{array}{c}\text { Current } \\
\text { Accounts }\end{array}$ & Microfinance & $\begin{array}{c}\text { Business } \\
\text { Loans }\end{array}$ & $\begin{array}{l}\text { Consumer } \\
\text { Loans }\end{array}$ & Mortgage & $\begin{array}{l}\text { Financial } \\
\text { Advice }\end{array}$ & $\begin{array}{c}\text { Investment } \\
\text { Products }\end{array}$ \\
\hline Client type of activity & $17 \%$ & $13 \%$ & $4 \%$ & $19 \%$ & $30 \%$ & $11 \%$ & $8 \%$ \\
\hline Sector & $11 \%$ & $17 \%$ & $27 \%$ & $14 \%$ & $15 \%$ & $5 \%$ & $33 \%$ \\
\hline Asset classes & $0 \%$ & $13 \%$ & $23 \%$ & $10 \%$ & $15 \%$ & $21 \%$ & $25 \%$ \\
\hline $\begin{array}{l}\text { Client personal } \\
\text { characteristics }\end{array}$ & $39 \%$ & $9 \%$ & $15 \%$ & $14 \%$ & $15 \%$ & $16 \%$ & $8 \%$ \\
\hline $\begin{array}{l}\text { Meets basic needs of the } \\
\text { community }\end{array}$ & $6 \%$ & $13 \%$ & $19 \%$ & $19 \%$ & $15 \%$ & $11 \%$ & $17 \%$ \\
\hline Quality of life indicators & $11 \%$ & $35 \%$ & $12 \%$ & $24 \%$ & $10 \%$ & $32 \%$ & $8 \%$ \\
\hline $\begin{array}{l}\text { No specific social impact } \\
\text { objective exists for this } \\
\text { product }\end{array}$ & $17 \%$ & $0 \%$ & $0 \%$ & $0 \%$ & $0 \%$ & $5 \%$ & $0 \%$ \\
\hline Total & $100 \%$ & $100 \%$ & $100 \%$ & $100 \%$ & $100 \%$ & $100 \%$ & $100 \%$ \\
\hline
\end{tabular}

Impact is also designed differently for target customer groups, namely, individual clients and small and medium enterprises. Individual clients are typically targeted directly. These are households, migrants/refugees, solo entrepreneurs, low income and credit- 
challenged individuals, amongst others. There are also impact areas that are targeted indirectly, that is, through the activities of SME clients.

In the design of products and services values-based financial institutions consider both direct and indirect impact pathways and appear to distinguish these according to various categories of social, economic and environmental well-being (Figure 3). With the exception of housing, impact on all categories of well-being is largely indirect by design. The indirect nature of impact will be addressed further under Section 4.4.

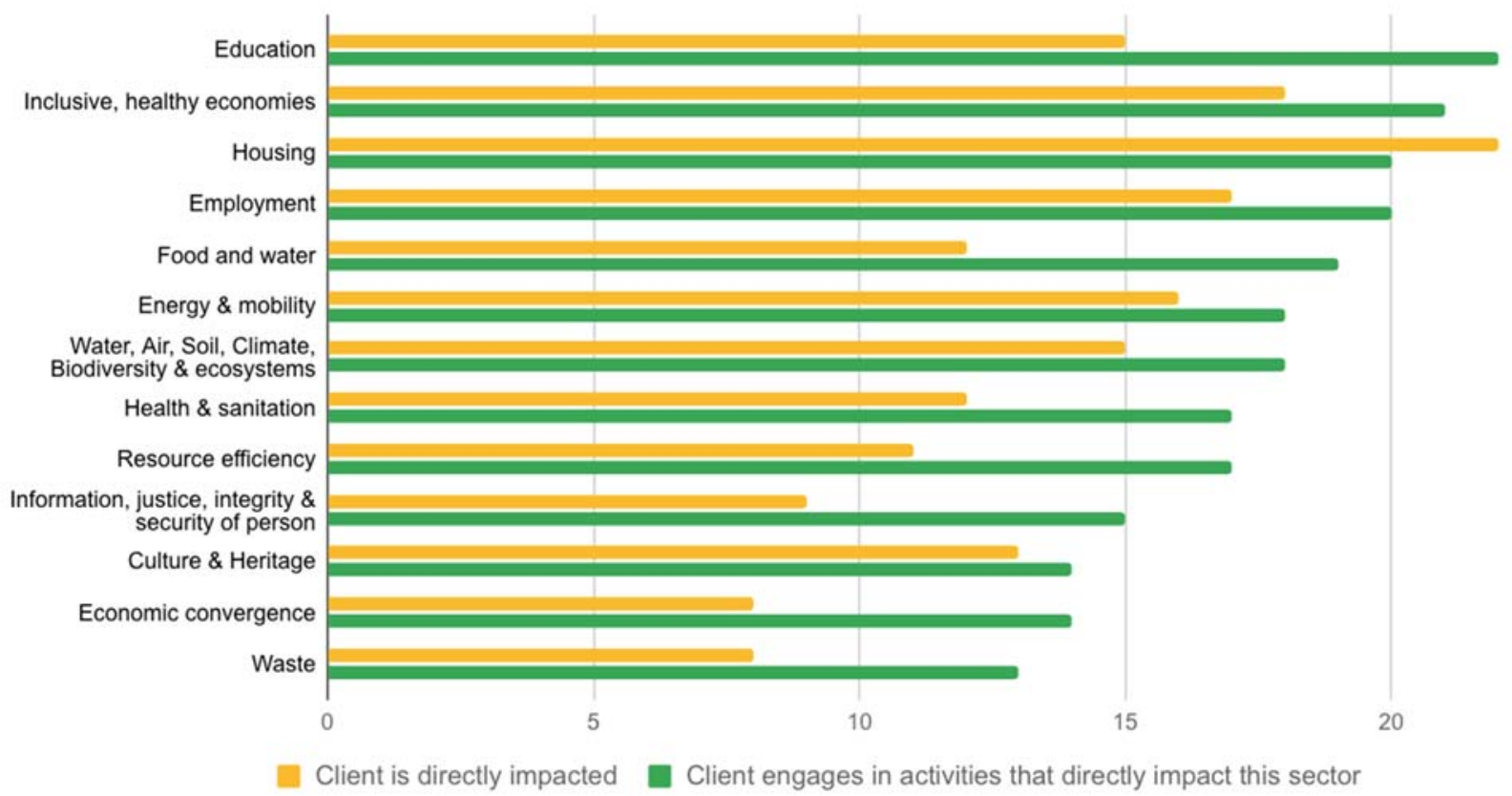

Figure 3. Sectors of impact and design impact approach of values-based financial institutions.

\subsubsection{Design That Prevents Locking-In Harm}

The focus on intentionality and positive impact notwithstanding, the large majority of values-based financial institutions design upfront products and services to do no harm. In the words of one CEO of a European bank that participated in the in-depth interviews: "Social inclusion is something we have done for decades. Our products and services have always been designed to be accessible to everyone and to address very specific environmental or social needs".

Negative impact for values-based financial institutions is more than the risk of significant harm to the borrower, employee, client, community and the environment because of the activity of the borrower. Negative impact risk is addressed directly in offered products and services and in policies to eliminate potential biases. It can also involve action in response to public policies that place roadblocks to efforts to address challenges (e.g., poverty) or enable resources (e.g., finance to support home ownership by families striving to increase their economic resilience and strength).

Exclusion lists identify activities, products and, in some cases, also transactions and practises that should not be financed because of the harm they cause [88-90]. Exclusion lists are an important tool to avoid doing harm and are by design comprehensive and ambitious.

\subsection{Practises Associated with the Implementation Stage}

Various dimensions are in play when designing social impact. The design approach of values-based financial institutions deals with complexity in structured ways that are 
aligned with their values. Hence, how values-based financial institutions handle this complexity in practise and do so effectively is particularly relevant.

\subsubsection{Social Impact: Not an Add-On}

Implementation refers to how values-based financial institutions deliver social impact. Making a difference, having a social impact is the responsibility of all co-workers rather than one department. The large majority of respondents reported that at least two-thirds of co-workers have social impact goals. From the Executive Board to relationship managers, impact and sustainability are integral to their roles.

Values-based financial institutions practise an embedded approach to impact; yet, some functions are more directly involved: executive management, product development, credit team, human resources, marketing and communications, risk management, branch governance and relationship managers.

Co-workers are seen as central to a successful implementation of social impact. Valuesbased financial institutions all agree on the importance of a better co-working environment with dignity and safety. Four-fifths of reported policies promote gender balance in wages and encourage innovation. Internal organisational coherence is key.

\subsubsection{Tools to Support Coherent Decision Making}

Values-based financial institutions report using financing and investment guidelines on the one hand, and impact transparency and client advisory protocols on the other $[88,91]$ to advance their values at the start of the underwriting process. Loan committees also support the implementation of social impact by including a loan's contribution to social impact in their assessment. One institution reported streamlining consumer loans that align with social objectives. Policies that cover environmental and social aspects are more widely used in support of social impact during loan origination.

Fewer than one-third of respondents reported relying on formal guidelines to resolve ethical dilemmas or trade-offs involving risk, return and impact, however. Experienced co-workers are important resources. In some institutions an internal steering committee decides on individual business loans. Looking ahead one of the respondents acknowledged a need to codify the standards and business principles they rely upon in their practise.

Values-based financial institutions are evenly split in their use of certifications or labels to support decision making and ensure the delivery of social impact priorities. Labels support decision making for clients operating in certain sectors especially organic agriculture and apparel. Certifications, mainly of the values-based financial institutions themselves, reflect local market practises and/or are linked to specific business models. The main certifications relevant to US respondents are Community Development Financial Institution (CDFI) and BCorp, while Latin American respondents pointed to client protection certification by SMART campaign.

\subsubsection{Organisational Change to Deliver Social Impact}

More than four-fifths reported evolving their business practises to deliver social impact. The changes were primarily to improve impact management, increase target of triple bottom line (TBL) assets to total assets, expand regions of operation, growing specific asset classes such as home lending to first home buyers, modifying lending criteria to allow lending to new types of clients, setting-up new units, enabling digital solutions, amongst others.

Social impact was part of the internal due diligence of more than two-thirds of respondents. It often involved all levels of the organisation, from the Board to relationship managers. Internal audit departments of close to two-thirds of respondents carry risk assessments that take performance on social impact and/or reputational risk into consideration. One respondent reported that reputational risk is an agenda item of the risk committee. Another noted that the Board of Directors and the Executive Board carries surveys and evaluates performance on social priorities and reputational risk taking into ac- 
count feedback from the internal audit department responsible for monitoring compliance with the Code of Corporate Conduct and Environmental and Social Policy.

Compliance with a growing number of regulatory requirements, risk restrictions and/or additional reporting does put pressure on values-based financial institutions yet not one institution reports this is in conflict with its social impact objectives. Values-based financial institutions note that resilient and financially viable institutions, who are in compliance with regulation to protect the rights of clients, are in fact better able to deliver social impact by adapting internal policies or diversifying services in the face of potential trade-offs that arise from regulatory and/or business tensions.

Boards of Directors play key roles including setting voluntary environmental and social commitments and ensuring that environmental and social regulatory requirements are met. At one institution, the Board establishes policy guidelines to meet the organisational requirements regarding an environmental and social management system that provides proper organisational structure and in-house capacity to identify environmental and social risks associated with clients and monitor risk mitigation plans. Internal audit verification that the assessment of social impact is correct may be carried out while reporting on public commitments, for example. Due diligence of vendors and rewards linked to progress implementing ESG principles are additional practises reported.

The Boards of more than two-thirds of respondents monitor progress on social impact. The indicators tracked vary and reflect the design approach of the institution (see Table 4). Their focus is on sectors, assets classes or clients of certain characteristics. They measure the number of loans, share of portfolio, number of clients or the full set of beneficiaries of banking products and services like the ambition to impact 250 million lives by 2025. In some instances, these targets are on top of those set by government authorities and central banks [92]. In the words of one CEO of a European bank that participated in the in-depth interviews: "KPIs reporting on social impact of our bank are discussed at the board of directors at least twice a year and are presented annually at the AGM".

Table 4. Items periodically supervised by Boards at values-based financial institutions.

\begin{tabular}{|c|}
\hline Monthly reports on loan distribution in economic sectors \\
\hline $\begin{array}{l}\text { Quarterly impact appetite framework [93] built using } 23 \text { indicators in the areas of environment, } \\
\text { social, governance, peace and ethical finance }\end{array}$ \\
\hline $\begin{array}{l}\text { Quarterly reports on organisational and management targets including social and environmental } \\
\text { aspects }\end{array}$ \\
\hline $\begin{array}{l}\text { TBL assets (see portfolio monitoring below), \# of volunteer hours of employees, } \% \text { of employees } \\
\text { volunteering, money provided in contribution or sponsorship to non-profit organisations }\end{array}$ \\
\hline Oversight of institution's CSR actions \\
\hline $\begin{array}{l}\text { Number of loans that reach the poor, impact of loans on the environment, targeting regions where } \\
\text { there are unbanked segments of the population }\end{array}$ \\
\hline Progress on the impact measurement and development of the GABV Scorecard \\
\hline Share of impact finance assets to total assets \\
\hline Proportion of mortgage lending on community housing \\
\hline $\begin{array}{l}\text { Outreach to rural loan clients, low-income clients, underbanked clients, plus jobs created by } \\
\text { agriculture and business loans }\end{array}$ \\
\hline
\end{tabular}

\subsubsection{Active Engagement}

Close client relations are central to the activities of values-based financial institutions. At several institutions, the communication with clients point to the difference that the values-based banking model offers for communities.

Counsellors work closely with clients in debt and struggling financially. Separately, innovation in products and services at one institution has been linked to specific achievements in connection with the well-being of its clients. Partnerships with organisations in 
the community are also part of the integrated model of values-based banking to reflect intentionality and coherence. Over the last 3 years, respondents focussed their efforts and intentions on their clients' economic resiliency, environmental regeneration and social empowerment. A focus on financial returns for investors was but fourth.

\subsection{Practises Associated with the Monitoring Stage}

Promoting social impact in a holistic way is key to values-based financial institutions. Their progress monitoring practises are tailored to their definition, design and implementation approach to social impact, with over two-fifths of respondents focusing on monitoring individual clients, over one-fifth on economic sectors, and under one-fifth on asset classes. Less prevalent amongst respondents is the practise of monitoring progress using quality of life indicators.

\subsubsection{Levels of Impact}

Although consistent reporting will help address risks of social- and green-washing it can neither adequately reflect the highly embedded approach to social impact of valuesbased financial institutions nor capture the strengths of this approach. Values-based financial institutions set to offer financing that is additional to the market, that is, better than the average in their context. The definition of additionality was clarified in coordination with MFR, the rating company.

Additionality implies a constant aspiration to push the frontier further: the same activity that brings additional impact today may not continue bringing additional impact in 10 years' time if progress is made in the general conditions and standards. The same activity may be of additional impact in one country and not in another country where the normal standards are higher.

The practise of classification of positive impact, both direct and indirect, varies according to how strict the criteria of what qualifies as positive impact are. Practises reported reflect the values-informed vision of the future, as well as challenges and resources as conditions that define social impact for values-based financial institutions.

For direct impact values-based financial institutions distinguish between minimum and sustainable. By direct minimum impact more than half of the respondents agree that providing financial access to underserved populations counts. By direct sustainable impact half agree that providing financial access to underserved populations and doing no significant harm to the environment counts. Other sources of direct sustainable impact are financing of SMEs that create and protect jobs while not significantly harming the environment. Underserved populations range from micro, small and medium entrepreneurs and individuals with low or no access to healthcare, quality education and exposure to climate risks. They may also refer to low-income clients in rural areas, unemployed, immigrants, people with low levels of education, individuals with low quality standards of living, those displaced, etc. Doing no harm at the level of individuals and SMEs means alignment with national law and regulations, human rights protection, corruption free, activities that do not impact the financial well-being of families, those that do not contribute to climate change, pollution, deforestation, industrial toxic waste, or require remediation.

For indirect impact respondents distinguish between minimum and transformative. Minimum indirect impact refers to activities that seek to address multiple and intersecting challenges. Transformative indirect impact refers to financing of clients transforming their business activities for sustainability and social impact and do not harm the environment. Examples of transformative indirect impact include SME expansion from micro to small and small to medium that create significant employment opportunities in the community and have at least one positive environmental impact. Another example of transformative indirect impact is financing for agricultural businesses that transform their irrigation systems away from diesel- to solar-powered systems. 


\subsubsection{Types of Monitoring}

Values-based respondents distinguish portfolio-level from client-level monitoring. This is particularly relevant for asset classes. Business loans and unlisted equity, commercial real estate and mortgages are mostly monitored at the portfolio level in accordance with GABV triple bottom line classification guidelines, examples of which can be shared upon request. This classification is ex post and more reliable when informed by data collected ex ante; that is, during credit underwriting. According to respondents, client-level monitoring is practised more often for mortgages as well as business loans. In addition to tracking performance at the client- and portfolio-level, values-based financial institutions also track performance at the programme-level.

The importance of monitoring lies in understanding what is working and where more needs to be done. The information collected is mostly in support of decision making, and to share with clients. The responses to the questionnaire and CEO interviews indicate that more and more values-based financial institutions are working to make explicit their social impact through structured and standardised reporting and to differentiate themselves from mainstream financial institutions.

\subsubsection{The Importance of the Process for Consistent Portfolio Monitoring}

Portfolio classification offers an ex post overview of the results of social impact efforts across all dimensions, yet its successful implementation requires careful steps. An overarching policy defining the goals, methodology, roles and responsibilities of the different levels of the organisations is useful to frame all the activities. Training and supervision of the personnel involved in the process are a fundamental complement to the methodology on paper.

Figure 4 illustrates the key steps of the process to classify a bank's intermediations in TBL and non-TBL, distinguishing the necessary components $(\sqrt{ })$ from the components that are considered as a plus (+). Triple bottom line refers to people, planet and prosperity. The process and figure were expanded with support from MFR and are based on GABV members' best practises.

The process may start with segmenting the assets according to a traffic light system based on their TBL and non-TBL likelihood in order to distinguish portfolio clusters for which an aggregate analysis is sufficient and those for which an individual approach is required. This step is important to calibrate the time investment required to classify portfolios. The graphic suggests some examples of products, sectors and purposes most likely to be TBL. Each financial institution develops criteria appropriate to its context.

After identifying the method of classification by segment, the TBL analysis is done, typically by loan officers or other front-line staff who enter the information into the core banking system, followed by TBL expert review (i.e., management level). Essential for quality classification are formalised classification criteria, escalating complex cases to managers or TBL experts, coaching of staff and clarification exchanges between loan officers and TBL experts. Ideally, the review by the TBL expert systematically covers the complex classification cases and larger loans and covers on a sample basis (at least) the remaining loans. The review uses the core banking systems and available loan documents. The individual classification is usually done ex ante (part of the loan assessment), while the aggregate classification is typically conducted and reviewed ex post, at a set frequency (from monthly to yearly).

It is critical that the TBL experts document all the exceptions, motivations and new criteria and elements used during the aggregate classification and the individual classification review (new cases to include and to exclude from TBL). This is very important to upgrade the methodology, at least yearly, with additions, clarifications and possibly new data to collect (iterative, circular process). 


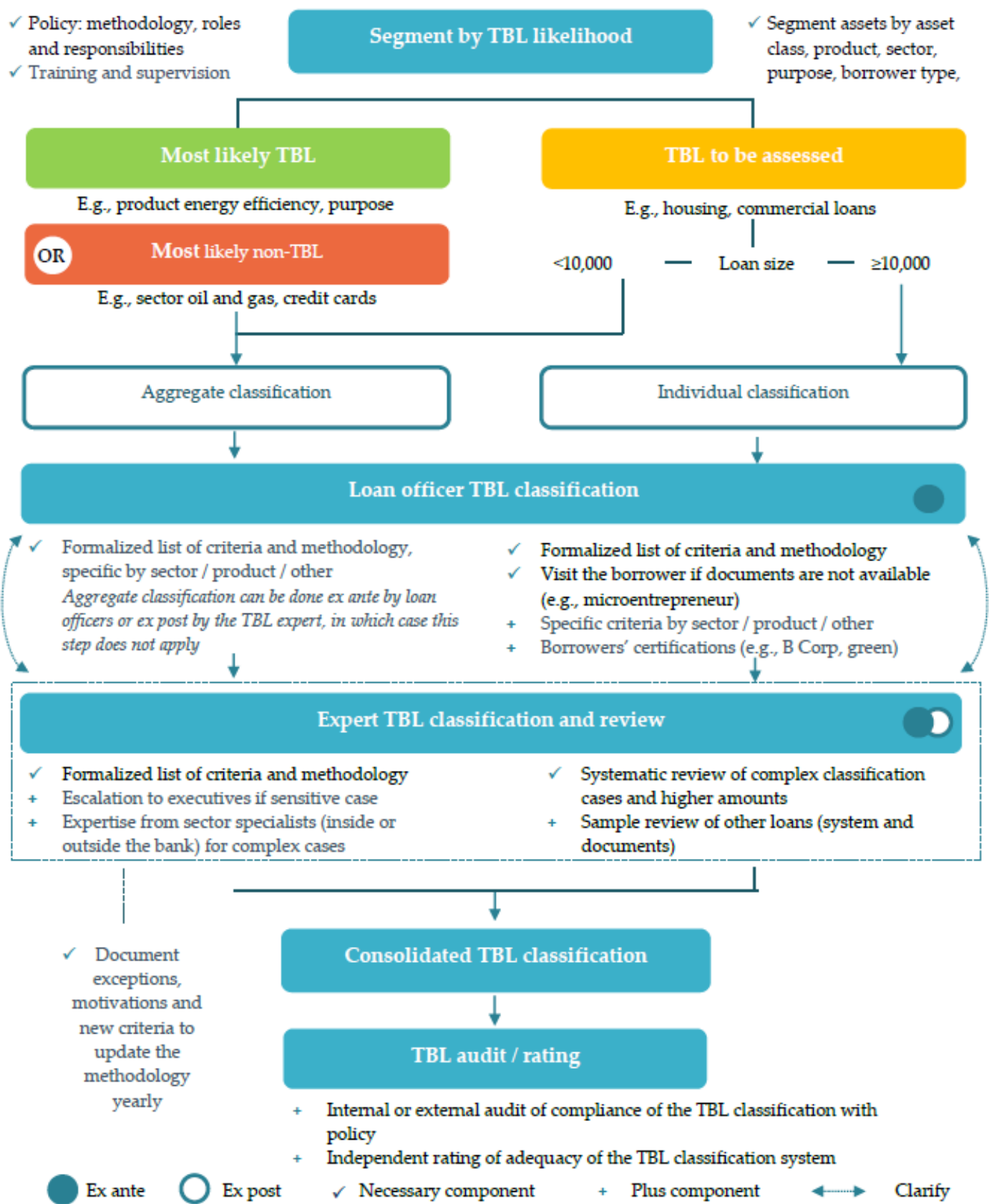

Figure 4. Best practise approach to TBL classification. Note: MFR prepared this extended graphic reflecting GABV members' TBL classification practices.

When higher credibility is needed (e.g., for internal incentive schemes or external visibility), the TBL classification can be included in the scope of the external audit (i.e., sample-based verification of the compliance of classification practise to the bank internal policy) or be rated by an independent third party (i.e., assessment of the adequacy of the TBL classification method and, over time, benchmark of results). Formalisation of the methodology and criteria is important for auditing and rating.

\subsubsection{Indicators of Impact}

The integrated approach to social impact of values-based financial institutions is seen in the relatively discrete indicators used to capture changes mainly in the number of resources financed; that is jobs, housing, education, etc., and linked to the values of the institutions. These indicators speak of inputs and outputs; on their own not that different 
from those used more broadly. Yet, there is an important difference. It lies in their being an explicit link to the definition, design and implementation stages of the social impact approach of the values-based financial institutions.

Table 5 lists examples of indicators by customer group. The indicators represent one piece of information, and one proof point of performance. They capture ex ante characteristics of borrowers, such as income, and sector that institutions prioritise and ex post performance implementing the designed approach to social impact. The latter includes indicators that reflect a deeper commitment to empowerment of clients (see indicators in the Additional column).

Table 5. Selection of reported indicators used to track performance in advancing social impact.

\begin{tabular}{|c|c|c|}
\hline Customer Group & Minimum & Additional \\
\hline \multirow[t]{2}{*}{$\begin{array}{c}\text { Start-ups without an organisational } \\
\text { structure }\end{array}$} & Jobs created (output) & Jobs retained \\
\hline & Clients funded (output) & $\begin{array}{l}\text { Clients supported in formulation of } \\
\text { business start-up plans } \\
\text { Referrals to government-affiliated } \\
\text { financial institutions for start-up support }\end{array}$ \\
\hline & $\begin{array}{l}\text { Income of borrower as percent of average } \\
\text { median income (input) }\end{array}$ & \\
\hline \multirow[t]{2}{*}{ Micro, small and medium enterprises } & $\begin{array}{l}\text { Share of loans to micro enterprises in } \\
\text { portfolio (output) }\end{array}$ & \\
\hline & Number served by programme (output) & $\begin{array}{c}\text { Cases of main business support } \\
\text { Cases of business succession support } \\
\text { Cases of M\&A support }\end{array}$ \\
\hline \multicolumn{3}{|c|}{$\begin{array}{l}\text { Ownership by underserved clients, } \\
\text { women, people of colour (input) }\end{array}$} \\
\hline \multicolumn{3}{|c|}{$\begin{array}{l}\text { Organisational structure is } \\
\text { mission-focussed (non-profit, } \\
\text { cooperative, etc.) (input) }\end{array}$} \\
\hline & $\begin{array}{c}\text { Corporate practises including no } \\
\text { corruption and compliance with labour } \\
\text { laws (input) }\end{array}$ & $\begin{array}{l}\text { Hiring practises for disadvantaged } \\
\text { groups (input) }\end{array}$ \\
\hline & $\begin{array}{l}\text { Sector including housing, education, } \\
\text { healthy food, etc. (input) }\end{array}$ & Transactions \\
\hline Large enterprises ( $\geq 250$ employees) & $\begin{array}{l}\text { All of the above plus: } \\
\text { Loans and advances (input) }\end{array}$ & \\
\hline \multicolumn{3}{|c|}{ Quality of trade portfolios (input) } \\
\hline \multicolumn{3}{|c|}{ Compliance } \\
\hline \multicolumn{3}{|c|}{ Digitisation } \\
\hline Individual customers & $\begin{array}{c}\text { Share of rural clients or other low-income } \\
\text { areas (output) }\end{array}$ & \\
\hline
\end{tabular}


Table 5. Cont.

\begin{tabular}{ccc}
\hline Customer Group & Minimum & Additional \\
\hline & First time home buyers (output) & Increase in net worth and savings \\
\hline Community-led housing (output) & Access to basic banking services \\
including credit (output) & $\begin{array}{c}\text { Number of credit-challenged individuals } \\
\text { who have participated in special } \\
\text { programmes, including payment } \\
\text { flexibility, non-citizens }\end{array}$ & Progress in well-being \\
\hline Green homes financed (output) & Homes suitable for people with \\
disabilities (output) & Repayment rate (output) & Repayment attitude and savings \\
\hline Average loan amount for small lending & (output) & Interest rate reductions for customers \\
\hline Credit score improvements (output)
\end{tabular}

\subsection{Continuous Adjustment (Feedback Loop)}

In a way, the last stage of value-based banking best practises to achieve social impact would be the strategic reflection that allows values-based financial institutions to learn from the whole process and leverage on social impact to achieve a larger market share and to scale-up their business.

The scaling-up approach differs significantly depending on the analysed financial institution, and it is also affected by the abovementioned set of three fundamentals: values/challenges/resources. The level of ambition of each financial institution is different and is deeply linked to the interpretation of these three fundamentals.

In-depth interviews with a sample of CEOs reflect that the opportunity of leveraging on social impact and scaling up the business is only considered and partially practised by some. Here are described some of the obstacles to scale-up the approach of values-based financial institutions:

- In some cases, social challenges that affect a specific market are in themselves a limitation for growth and scaling-up impact;

- $\quad$ Regulatory constraints, such as credit risk concentration per sector or activity, might act as a clear limitation to scale-up impact even though the bank has processes and policies in place that would allow it to achieve a better position;

- The relative scarcity of resources of some values-based financial institutions prevent them from scaling-up social impact with more ambition;

- Attention to overall consistency to values makes joint transactions with banks or traditional operators rare although that could bring a significant increase in the impact market;

- Furthermore, in a limited number of cases the very same values of the bank itself restrict its activities to a niche, which makes scaling up more challenging.

For a series of reasons that are described above, scaling-up of social impact faces some challenges. However, some more considerations arose from the interviews that pointed out how to handle those obstacles:

- Firstly, the specificity of the market should not be understood to suggest that positive social impact is limited to certain sectors;

- Secondly, values-based financial institutions, although generally growing fast, are managed in a prudent and sound way, and this, in some sense, poses a limitation to faster growth. A strategic process of scaling-up is generally not planned by the single bank, but may be helped by external players. 
Our findings clearly reflect that values-based financial institutions are practicing a clear social impact model with relevant best practises at each stage. A general model shows that social impact evaluation may act in strict connection with managing best practises and interaction with control systems.

It also shows a strong positive impact by retail and, in some cases, institutional customers. The performance and risk profile of the financial institutions adopting the values-based banking model were good and, in some cases, better than the ones shown by traditional mainstream banks [70,71].

This model is connected to the values of the interviewed financial institutions but could theoretically be applied to other banks or promoted by regulators.

To overcome the limitations that affect scaling-up social impact by values-based financial institutions, a better understanding of the evolution of sustainable investment and credit markets is needed, both in terms of customer behaviour, new impulses from regulators and the potential increase in the number of enterprises that transform into sustainable businesses.

Moreover, given the exploratory nature of this research, a deeper investigation of values-based financial institutions and finding ways of scaling them up would be a potential next step in our research.

\section{Discussion}

The concept of sustainable banking is strongly linked to the recognition of the accountability of banks to society, giving birth to concepts such as ethical banking or values-based banking and corporate social responsibility [32]. The birth and growth of the GABV as an alliance of frontrunners is clearly linked to that recognition. For GABV financial institutions the main driver is positive social and environmental impact; profitability, while needed, is only a consequence of impact. The GABV has a social position that is coherent with the World Benchmarking Alliance framework [78].

Both literature as well as preliminary interviews conducted with CEOs and other executives and experts of GABV financial institutions to build the structure of the questionnaire that, amongst other methodological tools, supported this research, showed the applicability and circularity of the four phases—define, design, implement and monitor-or rather four plus one if we include scale-up, which was consistently mentioned in all in-depth interviews with CEOs of the analysed financial institutions.

Building on this largely exploratory research study, we can extract the social impact virtuous cycle model practised by values-based financial institutions with the four plus one phases (see Figure 5).

The social impact virtuous circular model likely contrasts with the different, nonsystemic approach followed by other financial institutions, although due to the exploratory nature of this research, this cannot be concluded from our article. Instead, it can be considered a hypothesis that can fuel further research in the future.

At the stage of definition, the literature shows a lack of consensus including multiple descriptions of what we can consider defining social impact [33-35]. For the members of the GABV social impact is at the heart of their business model. In general terms, the best practises analysis shows that the definition of a positive contribution to impact has three fundamentals: (1) values to inform decisions and the direction of the journey; (2) social, economic and/or environmental challenges; (3) resources that address challenges and embody values to transform. This definition distinguishes between challenges that need to be addressed, values that must be nurtured to transform our societies, and the specific resources that are enabled by the banking activity (see Figure 6). 


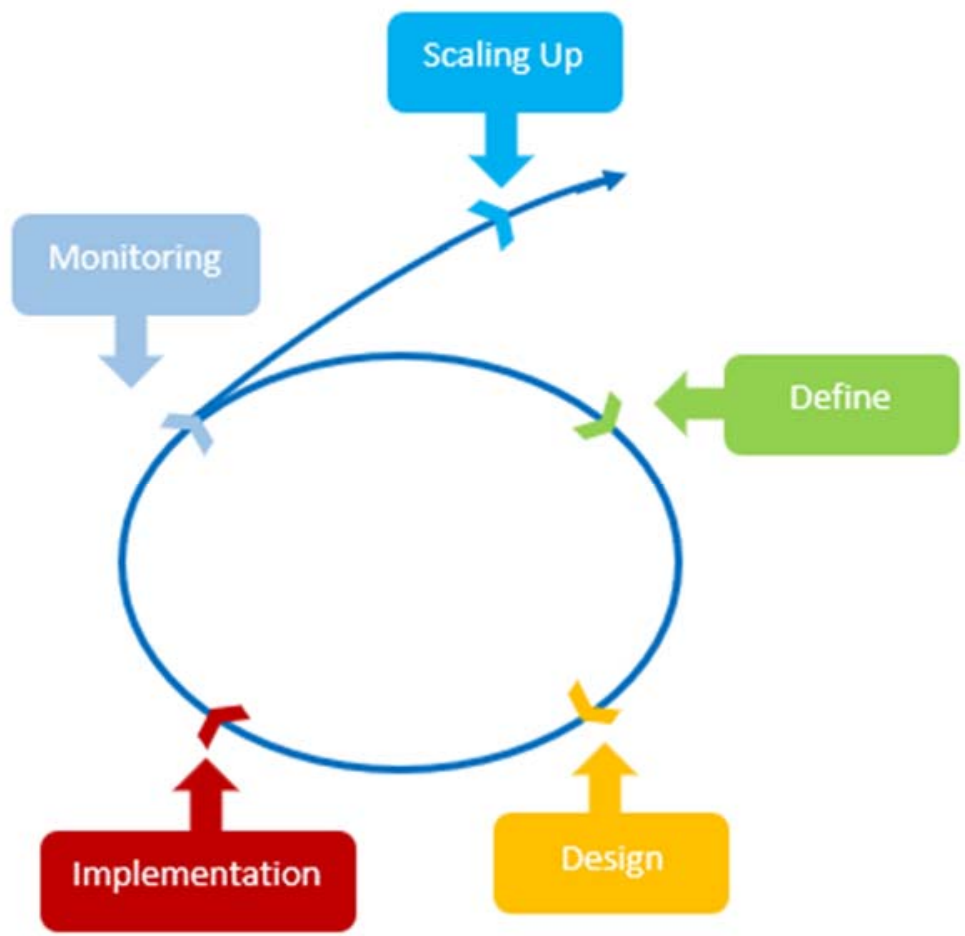

Figure 5. The social impact virtuous circular model practised by values-based financial institutions.

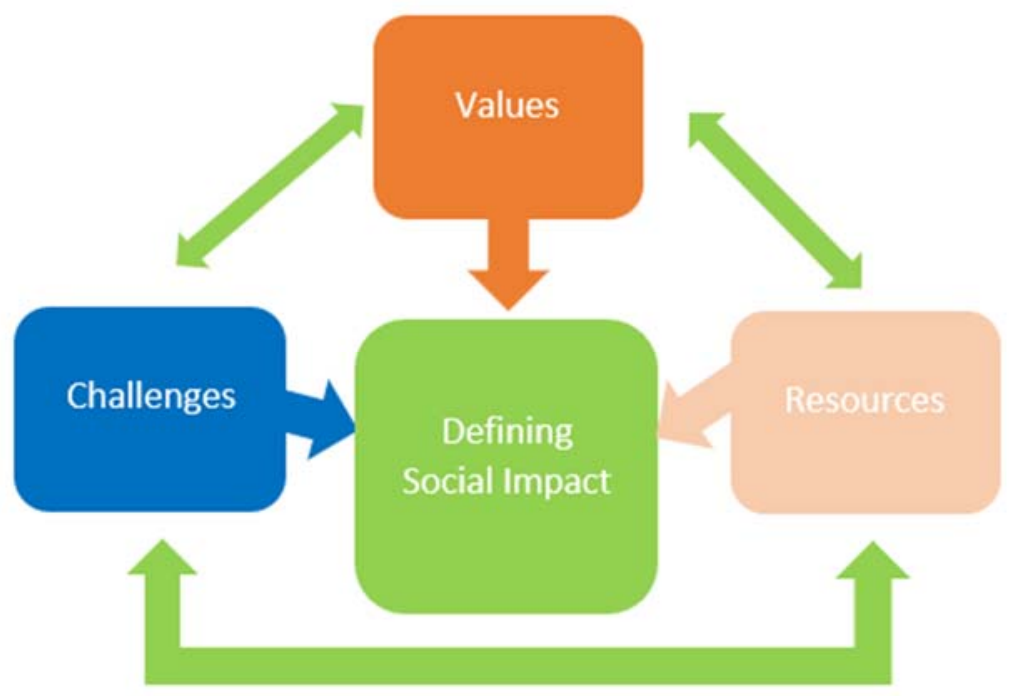

Figure 6. Best practises: the three fundamentals in the definition of social impact by values-based financial institutions.

The results allow us to complete best practises sub-models for each stage of the social impact virtuous circular model.

At the stage of design, different sources, such as the Impact Radar developed by the UNEP FI Positive Impact Initiative (PII), suggest its importance to achieve positive impact, particularly relative to products and policies. In general, the practise of valuesbased financial institutions in the design stage is characterised by a holistic flow from the "why" (high-level direction), the "how" (through products and services, guidelines and prioritisation), to the "what" (identifiable expected results for products and services in terms of direct and indirect impact and do no harm). Based on the above findings, we can 
also complete a best practises sub-model for this stage of the social impact virtuous circular model (see Figure 7).

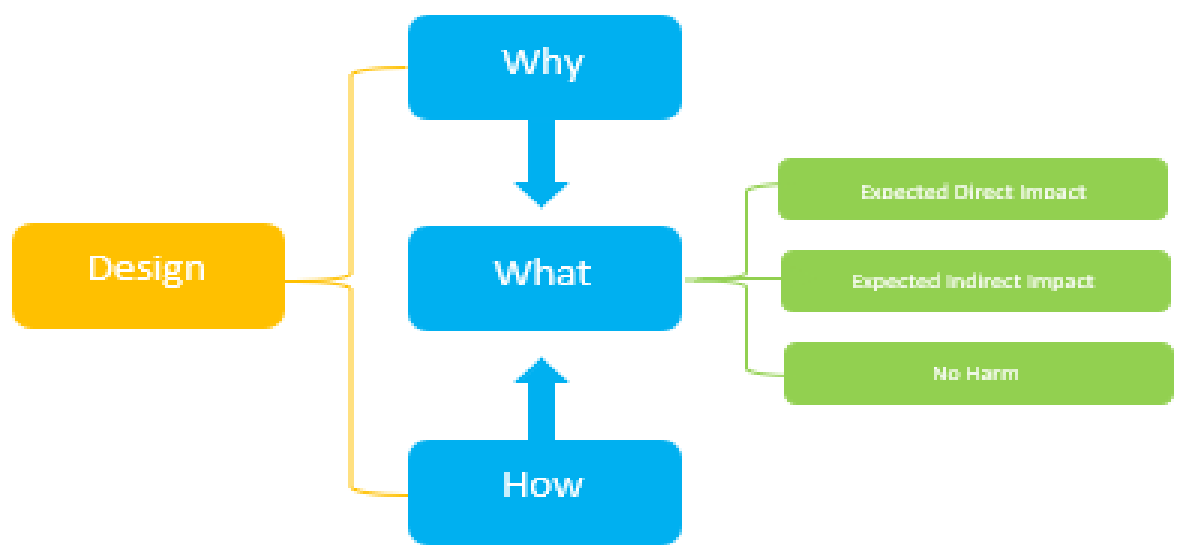

Figure 7. Best practises of a holistic design approach to social impact of values-based financial institutions.

At the stage of implementation, the literature emphasises the importance of coherence $[43,50,51]$ in all the different dimensions of the banking value chain: policies, internal operations, products, corporate governance, advocacy and lending practises. Our results are consistent with previous references and show that values-based financial institutions best practises at this stage reflect an embedded approach to implementing impact, highlighting the facts that most functions in the company are involved, that various types of policies and guidelines are in place to support implementation, that not only complying with regulatory requirements but also internal compliance is important, and that having the right experienced co-workers in an environment that protects dignity and safety is key for effective implementation. Once again, we can complete, based on the above findings, a best practises sub-model for the implementation stage of the social impact virtuous circular model (see Figure 8).

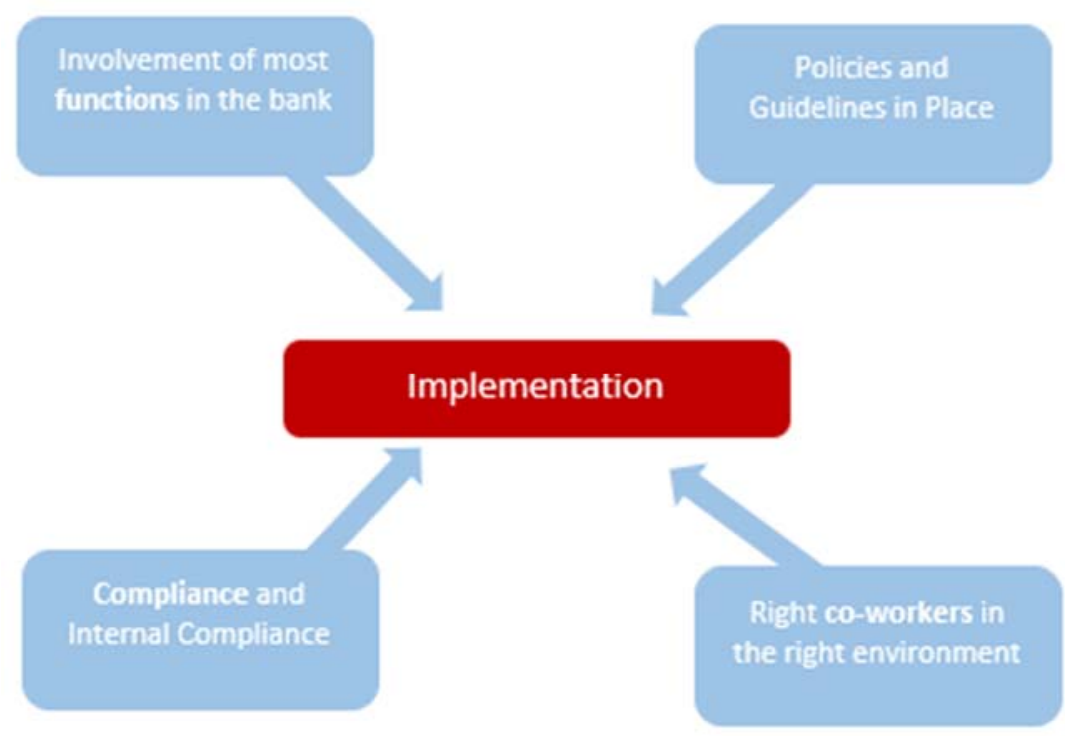

Figure 8. Best practises to consider when securing the implementation stage regarding social impact in values-based financial institutions.

Last but not least, at the monitoring stage there is an important consensus in the literature about the need for measurement, although many methods and approaches have 
been developed. Our results show that this is, indeed, an important stage for valuesbased financial institutions, who distinguish between portfolio-level (mainly ex-post) from client-level (ex-ante) and programme level (mixed) monitoring. Monitoring is particularly relevant for asset classes; business loans and unlisted equity, commercial real estate and mortgages are commonly although not exclusively monitored at the portfolio level in accordance with the GABV triple bottom line classification guidelines to determine whether an asset can be considered TBL or non-TBL. For direct impact, values-based financial institutions distinguish between minimum and sustainable impact and for indirect impact they distinguish between minimum and transformative impact (see Figure 9).

\section{Direct Impact}

- Minimum threshold

- Sustainable threshold

Indirect Impact

- Minimum threshold

- Transformative impact

\section{Classification guidelines: TBL vs. non-TBL likelihood}

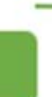
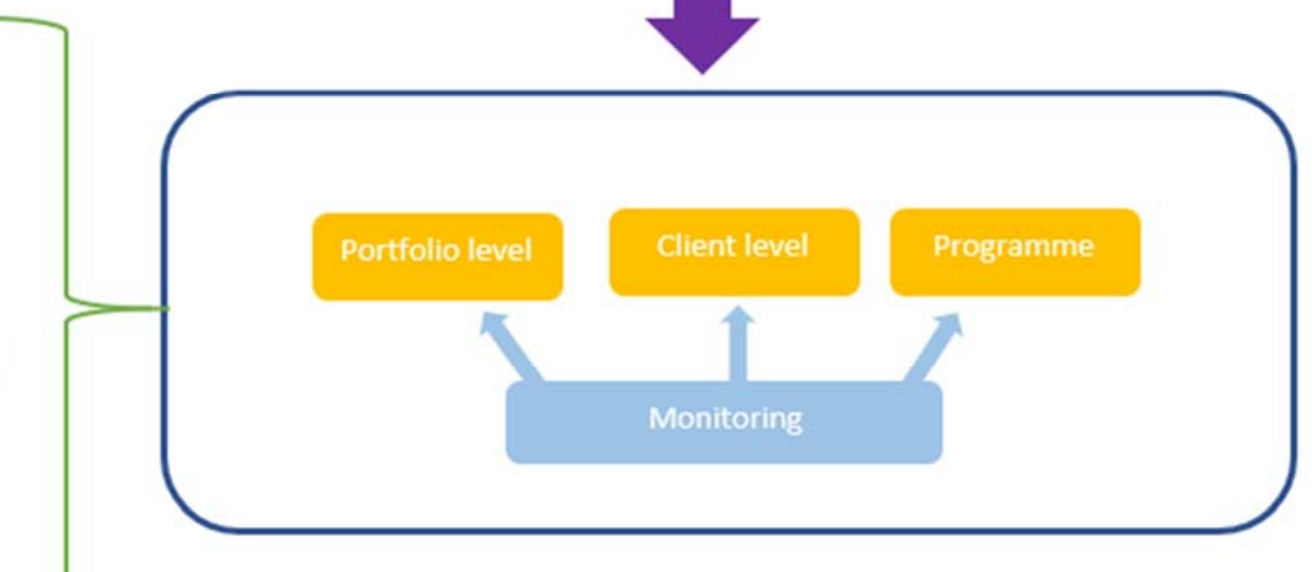

Figure 9. Best practises used in the monitoring stage of social impact by values-based financial institutions.

The scaling-up stage was not exactly a phase of the social impact virtuous circular model, yet the circular model is a precondition to achieve scaling-up. Our findings clearly reflect that values-based financial institutions are practising a clear social impact model with relevant best practises at each stage. However, scaling-up social impact, though it was evident, still found challenges and did not present common best practises that can be highlighted at this stage.

The complete social impact virtuous circular model practised by values-based financial institutions, including the circular model and the different sub-models for each stage, is described in Figure 10. 


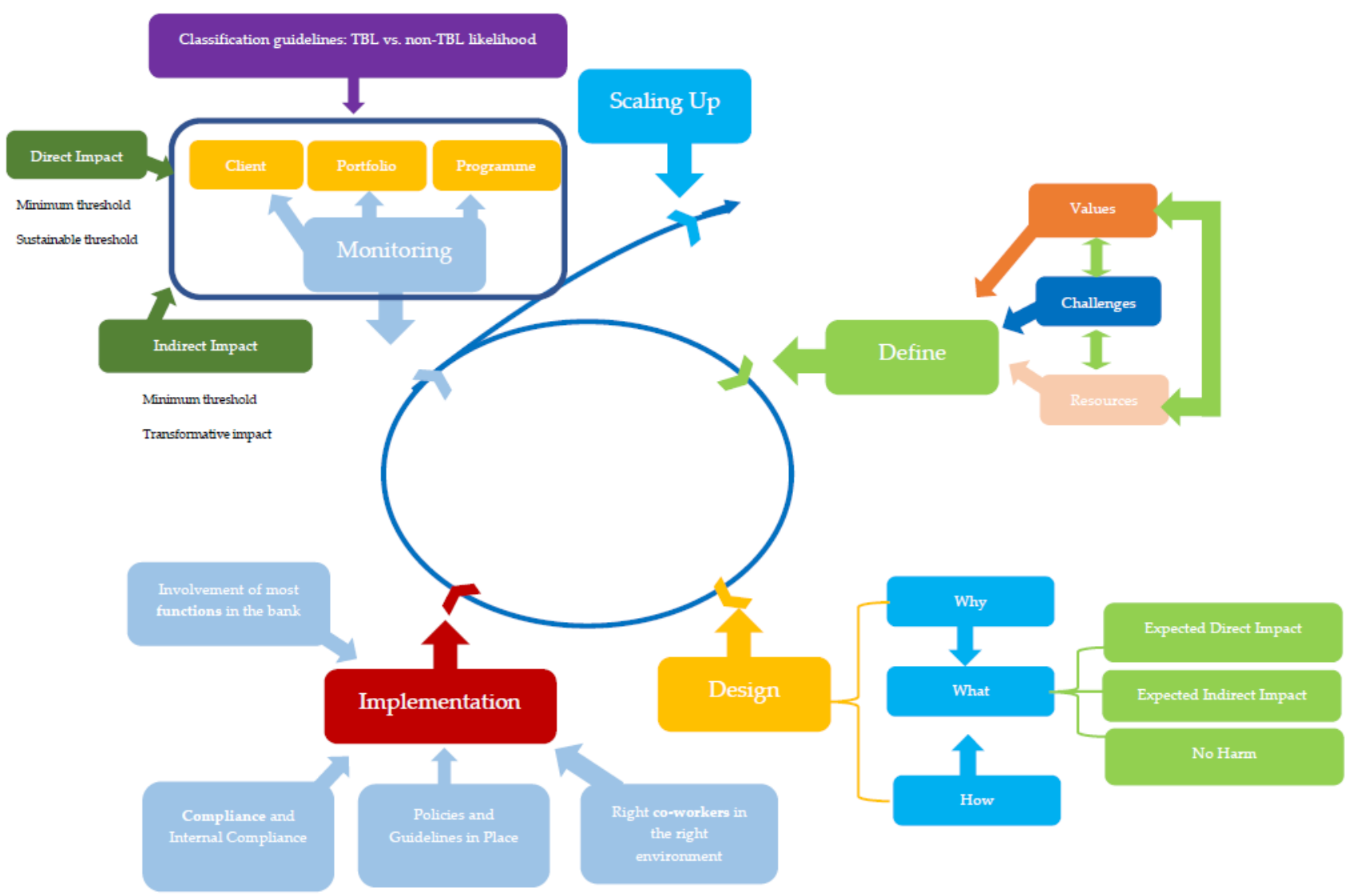

Figure 10. Social impact virtuous circular model practised by values-based financial institutions including the sub-models at each stage.

\section{Conclusions}

The achievement of positive social impact is a must for all economic activities, and it is very obviously a must for financial institutions in general and for banks, in particular, since they are working with other people's money to finance economic activities. This fact—using other people's money-stresses the moral need for banks to be especially aware of the need to generate positive social impact.

However, there is very little literature about the best practises used by financial institutions to achieve social impact. In the best of cases, we can find isolated examples and best practises linked to very concrete activities, especially related to the phases of definition and measurement of social impact, but we cannot find a coherent and comprehensive framework that integrates in a holistic and organised way the best practises of financial institutions regarding social impact, from the definition phase to the design, implementation, monitoring and scaling-up phases.

The social impact virtuous circular model, including the sub-models at each stage, practised by values-based financial institutions fills a gap in the literature about best practises to achieve social impact by financial institutions and about the pioneer role that values-based banking has played in the banking industry for decades. Choosing as the object of the investigation a cohesive group of banks, gathered around the Global Alliance for Banking on Values, a community well-known for its frontrunning spirit and its progressiveness in the way they have always looked at the essence of their banking activity, ensures the compilation of very strong best practises and a very solid circular framework.

The findings of this article and the subsequent best practises circular model that we have presented and its different sub-models can be an important resource for the academic community, especially for those researchers that are investigating the transformative role of finance and how we can create a more resilient and transformative financial system. As 
we have described in the discussion, there are several opportunities to extend our research that opens up new doors of investigation.

The circular model and the best practises we are presenting can be considered as a relevant and differential contribution for practitioners in the banking industry, since they show that it is possible to successfully embed the achievement of social impact in a business model as an integral pillar of a banker's role. Doing so also makes business sense.

This is why, although this article especially addresses the academic community it can also be a source of inspiration and thought for executives and practitioners in the financial industry and for bankers in particular. We find frontrunners in all industries, the ones that look ahead of the curve and that find new ways to address social challenges and improve the long-term sustainability of the industry by innovating in many different ways. Valuesbased banking has played this role in the banking industry through innovation. Valuesbased financial institutions are leading in the way that they deal with the environmental and social challenges of our times. The best practises social impact circular model is also a way to influence the financial industry.

Even though we have followed a rigorous methodology, this study has some limitations which, in turn, represent new opportunities for future research. Given the exploratory nature of this research, a deeper investigation of the scaling-up stage, identifying best practises and finding ways to overcome the limitations that affect scaling up social impact by values-based financial institutions, would be potential next steps. In addition, exploring whether the different sub-models for each stage of the social impact virtuous circular model practised by values-based financial institutions are also practised or are inspiring best practises in other financial institutions is also a potential area for future inquiry.

Author Contributions: Conceptualisation, A.K.-M. and M.E.H.; literature review, R.B.-V.; theoretical model, A.K.-M., R.B.-V. and M.E.H.; methodology, A.K.-M.; validation, A.K.-M., R.B.-V., and M.E.H.; formal analysis, A.K.-M. and M.E.H.; data curation, A.K.-M.; writing-original draft preparation, A.K.-M., R.B.-V. and M.E.H.; writing-review and editing, A.K.-M., R.B.-V. and M.E.H.; project administration, A.K.-M.; funding acquisition, A.K.-M. All authors have read and agreed to the published version of the manuscript.

Funding: This research was funded by the Open Society Foundation, VALoRE I Values RegulationEurope, grant number OR2020-72428.

Institutional Review Board Statement: Not applicable.

Informed Consent Statement: Not applicable.

Data Availability Statement: Access to the data upon request subject to approval of participating values-based financial institutions.

Acknowledgments: This work would not have been possible without the support and active involvement of Ugo Biggeri. We also want to express our profound appreciation to all participating institutions members of the GABV. These institutions devoted a significant amount of time to respond to the questionnaire. To the CEOs interviewed we thank you for your time and insights. Members of the expert review committee provided early feedback on the preliminary analysis of survey responses for which we are grateful. Thank you to Nina Magomedova, Adam Kurowski, Kush Saluja, and Andres David Estrada for their valuable inputs. In Adriana Kocornik-Mina's case, she gratefully acknowledges financial support from the Open Society Foundation. Any opinions expressed and any mistakes are our own.

Conflicts of Interest: The authors declare no conflict of interest. 
Appendix A. List of Participating Financial Institutions

\begin{tabular}{|c|c|c|c|}
\hline 1 & Amalgamated Bank (USA) & 16 & $\begin{array}{l}\text { Grooming Microfinance Bank } \\
\text { (Nigeria) }\end{array}$ \\
\hline 2 & Banca Etica (Italy) & 17 & $\begin{array}{l}\text { Kindred Credit Union } \\
\text { (Canada) }\end{array}$ \\
\hline 3 & $\begin{array}{l}\text { Banco Ademi (Dominican } \\
\text { Republic) }\end{array}$ & 18 & Magnet Bank (Hungary) \\
\hline 4 & $\begin{array}{l}\text { Banco Popular de Honduras } \\
\text { (Honduras) }\end{array}$ & 19 & MegaBank (Ukraine) \\
\hline 5 & Bank Australia (Australia) & 20 & $\begin{array}{l}\text { Clearwater Credit Union } \\
\text { (USA) }\end{array}$ \\
\hline 6 & Beneficial State Bank (USA) & 21 & $\begin{array}{l}\text { Opportunity Bank Serbia } \\
\text { (Serbia) }\end{array}$ \\
\hline 7 & BRAC Bank (Bangladesh) & 22 & Southern Bancorp (USA) \\
\hline 8 & Center-Invest (Russia) & 23 & Sunrise Banks (USA) \\
\hline 9 & Cultura Bank (Norway) & 24 & $\begin{array}{l}\text { The First Microfinance } \\
\text { Bank-Afghanistan } \\
\text { (Afghanistan) }\end{array}$ \\
\hline 10 & $\begin{array}{l}\text { Dai-Ichi Kangyo Credit } \\
\text { Cooperative (Japan) }\end{array}$ & 25 & Triodos Bank (Europe) \\
\hline 11 & $\begin{array}{l}\text { Decorah Bank and Trust Co. } \\
\text { (USA) }\end{array}$ & 26 & Umweltbank (Germany) \\
\hline 12 & $\begin{array}{l}\text { Ecology Building Society } \\
\text { (United Kingdom) }\end{array}$ & 27 & $\begin{array}{l}\text { Vancity Credit Union } \\
\text { (Canada) }\end{array}$ \\
\hline 13 & $\begin{array}{l}\text { Freie Gemeinschaftsbank } \\
\text { Genossenschaft (Switzerland) }\end{array}$ & 28 & Verity Credit Union (USA) \\
\hline 14 & $\begin{array}{l}\text { G\&C Mutual Bank Limited } \\
\text { (Australia) }\end{array}$ & 29 & Visión Banco (Paraguay) \\
\hline 15 & GLS Bank (Germany) & 30 & $\begin{array}{l}\text { VSECU (Vermont State } \\
\text { Employees Credit Union) } \\
\text { (USA) }\end{array}$ \\
\hline
\end{tabular}

\section{Appendix B. Questionnaire}

To realise its social impact objectives your institution has identified social needs and defined its social impact objectives. This section of the questionnaire is designed to understand how your institution defines social impact.

High-level overview questions

1. What is social impact for my bank?

a. My institution defines negative impact as

b. My institution defines positive impact as

2. How is your definition of social impact different from conventional banks? Please explain

3. How does my bank measure social impact on client and by client? Please explain

4. How does my institution capture the progress it makes in its social impact objectives? Please explain

5. What information do we use to calibrate our social impact thresholds? That is, when is our intermediation socially sustainable and when does it go further and is socially transformative? Please explain

6. What value does measuring social impact have for my bank and for its clients and communities? Please explain.

7. What evidence of impact do I report and share with stakeholders? Please explain

\section{End of high-level overview questions}

8. What social challenges do your communities experience? Please select the top three only 


\begin{tabular}{|c|c|c|c|c|}
\hline 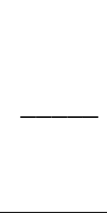 & $\begin{array}{l}\text { No poverty } \\
\text { (Poverty) }\end{array}$ & $\begin{array}{c}\text { Clean water } \\
\text { and } \\
\text { sanitation } \\
\text { (Lack of ... ) }\end{array}$ & $\begin{array}{l}\text { Sustainable } \\
\text { cities and } \\
\text { communities } \\
\text { (Unsustainable } \\
\ldots \text {.. ) }\end{array}$ & $\begin{array}{c}\text { Peace, justice } \\
\text { and strong } \\
\text { institutions } \\
\text { (Lack of ... ) }\end{array}$ \\
\hline & $\begin{array}{l}\text { Zero hunger } \\
\text { (Hunger) }\end{array}$ & $\begin{array}{c}\text { Affordable } \\
\text { and clean } \\
\text { energy } \\
\text { (Lack of ... ) }\end{array}$ & $\begin{array}{l}\text { Responsible } \\
\text { consumption } \\
\text { and } \\
\text { production } \\
\text { (Irresponsible } \\
\text {.. ) }\end{array}$ & $\begin{array}{c}\text { Partnerships } \\
\text { for the goals } \\
\text { (removed) }\end{array}$ \\
\hline & $\begin{array}{l}\text { Good health } \\
\text { and } \\
\text { well-being } \\
\text { (Poor... ) }\end{array}$ & $\begin{array}{c}\text { Decent work } \\
\text { and } \\
\text { economic } \\
\text { growth } \\
\text { (Lack of ... ) }\end{array}$ & $\begin{array}{c}\text { Climate } \\
\text { action } \\
\text { (Lack of ... ) }\end{array}$ & $\begin{array}{c}\text { Race and age } \\
\text { discrimina- } \\
\text { tion }\end{array}$ \\
\hline & $\begin{array}{l}\text { Quality } \\
\text { education } \\
\text { (Low ... ) }\end{array}$ & $\begin{array}{c}\text { Industry } \\
\text { innovation } \\
\text { and infras- } \\
\text { tructure } \\
\text { (Lack of ... ) }\end{array}$ & $\begin{array}{c}\text { Life below } \\
\text { water } \\
\text { (Threat to ... } \\
\text { ) }\end{array}$ & $\begin{array}{c}\text { Other (please } \\
\text { specify) }\end{array}$ \\
\hline & $\begin{array}{l}\text { Gender } \\
\text { equality } \\
\text { (Gender } \\
\text { inequality) }\end{array}$ & $\begin{array}{c}\text { Reduced } \\
\text { inequalities } \\
\text { (Growing ... } \\
\text { ) }\end{array}$ & $\begin{array}{c}\text { Life on land } \\
\text { (Threat to ... } \\
\text { ) }\end{array}$ & \\
\hline
\end{tabular}

9. Select only three, then rank order: What are your institution's top three priority social values informing your product design and offerings, as well as business practises (please rank order 1-3 with 1 being your top priority and 3 the third?

\begin{tabular}{ccc}
\hline & VALUES & Human dignity \\
\hline & - & Fairness \\
\hline & - & Inclusion \\
\hline & & Solidarity \\
\hline & & Affordability \\
\hline & Resilience \\
\hline & Well-being \\
\hline & Happiness \\
\hline & Diversity \\
\hline & Honesty \\
\hline & Cospeculation \\
\hline
\end{tabular}

10. If you selected "Other" in the previous question, please explain: 
11. Select only three, then rank order: What are your institution's top three priority social objectives informing your product design and offering, as well as business practises (please rank order 1-3 with 1 being your top priority and 3 the third)? (23)

\begin{tabular}{cc}
\hline & OBJECTIVES \\
\hline & Jobs \\
\hline & Equitable access to housing \\
\hline & Equitable access to food \\
\hline & Equitable access to healthcare \\
\hline
\end{tabular}

12. If you selected "Other" in the previous question, please explain:

13. Your institution offers products and services to clients operating in the following dimensions of well-being (check all that apply):

\begin{tabular}{|c|c|c|}
\hline & Client Is Directly Impacted & $\begin{array}{l}\text { Client Engages in Activity That } \\
\text { Directly Impacts These Sectors }\end{array}$ \\
\hline Social & 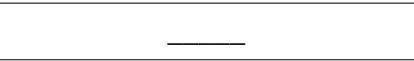 & - \\
\hline Food and water & 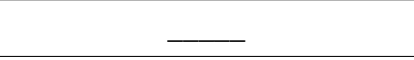 & 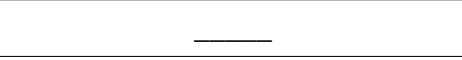 \\
\hline Housing & 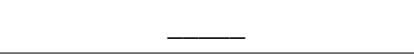 & - \\
\hline Health and sanitation & - & - \\
\hline Education & - & - \\
\hline Employment & $\underline{-}$ & 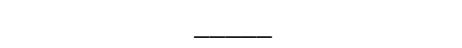 \\
\hline Energy and mobility & - & - \\
\hline Culture and Heritage & - & 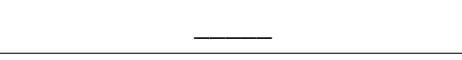 \\
\hline $\begin{array}{l}\text { Information, justice, integrity and } \\
\text { security of person }\end{array}$ & & \\
\hline Economic & $\longrightarrow$ & - \\
\hline Inclusive, healthy economies & 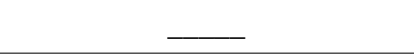 & - \\
\hline Economic convergence & - & 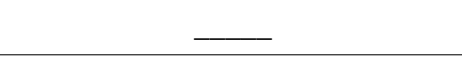 \\
\hline Environmental & - & - \\
\hline Resource efficiency & - & - \\
\hline Waste & - & - \\
\hline $\begin{array}{l}\text { Water, air, soil, climate, biodiversity and } \\
\text { ecosystems }\end{array}$ & & \\
\hline Other (please specify): & + & $\ldots$ \\
\hline
\end{tabular}

Your responses to the questions in this section give you an opportunity to elaborate on your institution's unique designed approach to realizing its social impact priorities. Please respond to these questions through the approach that is most relevant to your institution (see question 14)

14. Please select the statement that best describes your institution's approach to social impact (select only one): 


\begin{tabular}{c|c}
\hline & My approach to social impact is best described as responding to the challenges selected in question 8 above \\
\hline & My approach to social impact is best described as advancing the social values selected in question 9 above \\
\hline & My approach to social impact is best described as advancing the social objectives selected in question 11 above \\
\hline & $\begin{array}{c}\text { My approach to social impact is best described as advancing the dimensions of well-being selected in question } \\
13 \text { above }\end{array}$ \\
\hline
\end{tabular}

15. My institution is confident that its products and services advance its social impact targets for the following reasons (rank order from most important to least important (with 1 being the highest and 6 the lowest):

\begin{tabular}{c|c}
\hline & Impact targets are embedded in product and service design \\
\hline- & We do not finance sectors that are harmful \\
\hline- & We measure and report progress using our own indicators \\
\hline- & Our strategy, processes and actions are designed to deliver on social impact objectives \\
\hline- & My institution has a "do no harm" policy (please include) \\
\hline- & $\begin{array}{c}\text { My institution relies on an exclusion list based on internationally conventions and activities commonly } \\
\text { recognised as harmful (please include) }\end{array}$ \\
\hline & Other \\
\hline
\end{tabular}

16. If you selected "Other", please explain:

17. Impact target design by my institution is driven by one or more of the following in order of importance (with 1 being the highest and 5 lowest):

Asset classes (e.g., commercial real estate, mortgages, business loans)
Economic sector (agriculture, manufacturing, etc.)

18. If you selected "Other", please describe:

19. Please rank order your current social impact target customer groups (1 is most targeted and 6 least targeted):

\begin{tabular}{c|l}
\hline Start-ups without an organisational structure & \\
\hline Micro enterprises (below 10 employees) & \\
\hline Small enterprise (below 50 employees) & \\
hline Medium enterprises (below 250 employees) & \\
\hline Large enterprises with 250 employees or above & \\
\hline Individual customers & \\
\hline Other (please explain) & \\
\hline
\end{tabular}

20. If you selected "Individual customers", please describe them

21. If you selected "Other", please explain

22. What factors are important in the design of products that deliver social impact. For each product (column), please rank order your responses $1-8$, with 1 being the most relevant to 8 being the least relevant: 


\begin{tabular}{|c|c|c|c|c|c|c|c|c|}
\hline Type of Product & $\begin{array}{l}\text { Current } \\
\text { Accounts }\end{array}$ & $\begin{array}{c}\text { Savings } \\
\text { Accounts }\end{array}$ & Microfinance & $\begin{array}{l}\text { Short-Term } \\
\text { Loans }\end{array}$ & $\begin{array}{l}\text { Long-Term } \\
\text { Loans }\end{array}$ & Mortgages & $\begin{array}{l}\text { Financial } \\
\text { Advice }\end{array}$ & $\begin{array}{l}\text { Investment } \\
\text { Products }\end{array}$ \\
\hline Asset classes & $\underline{-}$ & 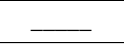 & $\underline{-}$ & $\ldots$ & - & $\ldots$ & - & 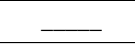 \\
\hline Sector & $\underline{-}$ & $\underline{-}$ & $\underline{-}$ & $\underline{-}$ & $\underline{-}$ & $\underline{-}$ & 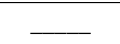 & $\underline{-}$ \\
\hline Client personal characteristics & $\underline{-}$ & $\underline{-}$ & $\underline{-}$ & $\underline{-}$ & $\underline{-}$ & $\underline{-}$ & 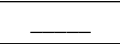 & $\underline{-}$ \\
\hline Client type of activity & - & 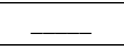 & - & - & 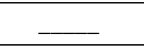 & 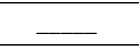 & 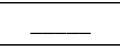 & $\longrightarrow$ \\
\hline $\begin{array}{l}\text { Meets basic needs of the } \\
\text { community }\end{array}$ & - & - & $\bar{z}$ & $\bar{\square}$ & 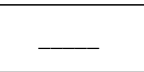 & - & $\longrightarrow$ & $\longrightarrow$ \\
\hline Quality of life indicators & - & - & - & - & - & - & - & 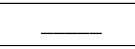 \\
\hline $\begin{array}{c}\text { No specific social impact } \\
\text { objective exists for this product }\end{array}$ & - & $\longrightarrow$ & $\longrightarrow$ & - & 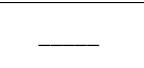 & $\longrightarrow$ & $\longrightarrow$ & 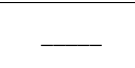 \\
\hline \multirow[t]{2}{*}{ Other } & 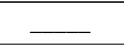 & 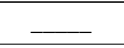 & $\longrightarrow$ & - & 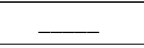 & 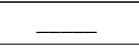 & 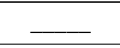 & - \\
\hline & & & \multicolumn{2}{|c|}{ Other (please specify) } & & & & \\
\hline
\end{tabular}

23. Products and services are designed upfront to do no harm and your institution provides evidence that they do no harm in practise

Yes

Your institution has developed an approach to delivering on its social impact priorities. The following questions are designed to capture the key elements of this approach with a focus on your top three social impact priorities (as indicated in your answer to question 14):

24. What percent of co-workers are dedicated to advancing the social impact priorities of your institution (please give your best estimate)?

\begin{tabular}{l|c}
\hline & Less than 10\% \\
\hline- & Around 25\% \\
\hline- & Approximately $50 \%$ \\
\hline- & Close to $75 \%$ \\
\hline & Pretty much everyone \\
\hline
\end{tabular}

25. Which departments in your institution are responsible for delivering on your institution's social priorities?

26. How do these departments contribute to advancing social benefits for its clients and other stakeholders? If protocols and/or checklists are used, please send these to adriana.kocornik@gabv.org with the subject line "q26 checklists".

27. How does your institution resolve trade-offs that arise because of regulatory and/or business tensions when advancing its social impact priorities?

28. My institution has defined guidelines on how to resolve potential ethical dilemmas and trade-offs involving risk, return and impact considerations that reflect its level of tolerance. Please send these guidelines to adriana.kocornik@gabv.org subject line "q28 guidelines".

\begin{tabular}{c|c}
\hline Yes & \\
\hline No & \\
\hline Other (please specify) & \\
\hline
\end{tabular}

29. Does your institution have systems in place to track progress on meeting social priorities?

Yes

No

30. If yes, are these your own systems or are these provided by a third party (please include the name of the third party)?

31. Do you use certifications or labels to support your decision making and ensure the delivery of social impact priorities?

Yes

No

32. If yes, please list these certification or labels: 
33. Is progress on social impact priorities part of your internal due diligence?

$$
\begin{aligned}
& \text { Yes } \\
& \text { No }
\end{aligned}
$$

34. If yes, please describe how:

35. Does your institution have social impact targets that are monitored by the Board?

Yes

No

36. If yes, please state what it is:

37. Is your internal audit department carrying out its risk assessment of the bank taking into account its performance on social impact factors and/or reputational risk?

Yes

38. If yes, please elaborate:

39. Has your institution been evolving your business practises in order to deliver on its social impact priorities? Yes No

40. If you answered yes, please describe the changes in your organisation:

41. My institution is coherent in its commitment to social impact priorities as it has (please select all that apply):

\begin{tabular}{c|c}
\hline & Gender balance in wages \\
\hline- & Dignity and safety: better co-working environment \\
\hline- & Encourage innovation \\
\hline & Other (Please specify) \\
\hline
\end{tabular}

42. For managers and co-workers, do you connect variable wages not just to economic performance indicators but also to social impact results?

Yes

No

43. If yes, please describe how:

Your institution may have developed an approach to monitoring progress in delivering its social impact priorities. The following questions are designed to capture the key elements of this approach with a focus on your top three priorities as indicated in your answer to question 14:

44. My institution monitors progress on delivering social targets with a focus on (select only one):

\begin{tabular}{cc}
\hline & Economic sector \\
\hline & Asset class \\
\hline & Quality of life indicators \\
\hline & Individual and/or type of organisation \\
\hline
\end{tabular}

45. My institution monitors progress in delivering on the institution's social impact priorities for the following asset classes (Yes/No for all that apply) 


\begin{tabular}{cll}
\hline Asset Class & Portfolio-Level & Client-Level \\
\hline Listed equity and corporate bonds & - & \\
\hline Business loans and unlisted equity & - & \\
\hline Project finance & - & - \\
\hline Commercial real estate & - & \\
\hline Mortgages & - & \\
\hline Motor vehicle loans & & \\
\hline Other & & \\
\hline Other (please explain): & & \\
\hline
\end{tabular}

46. If appropriate, please list the indicators used to track progress on your institution's social impact priorities by relevant customer group:

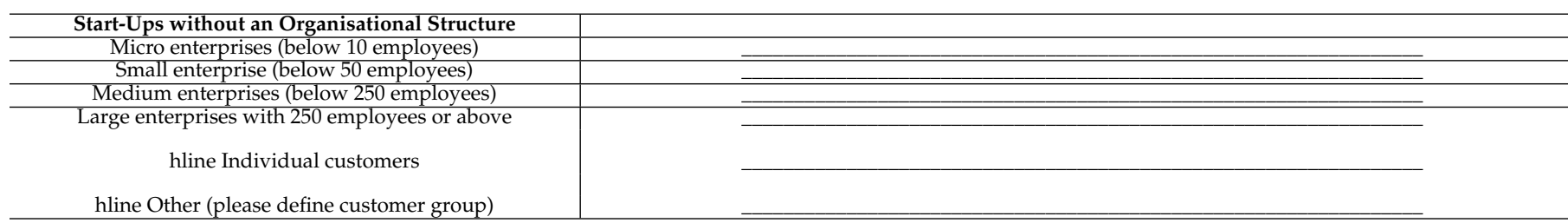

47. How would you rate the precision of the data your institution has to track progress on its social impact priorities?

\begin{tabular}{c|c}
\hline & Precise \\
\hline Asset classes & - \\
\hline Economic sector & \\
\hline Client personal characteristics & - \\
\hline Meets basic needs of community & - \\
\hline Quality of life indicators & \\
\hline Other (please describe): & \\
\hline
\end{tabular}

48. Please enter AGREE only for those statements that most appropriately describe your institution's current approach to measuring its positive social impact:

i.

Minimum: My institution counts its activities as creating positive social impact IF they provide financial ACCESS to underserved populations

Please provide your definition of what constitutes underserved population:

ii.

Sustainable: My institution counts its activities as creating positive social impact IF they provide financial access to underserved populations AND do not significantly harm the environment

Please define what no significant harm means for your institution

i.

iii.

iv.

vi.

vii.

Sustainable: My institution ONLY counts its activities as positive social impact if it finances SMEs that create or protect jobs AND do not significantly harm the environment

that would otherwise NOT be available to the underserved population

... that are ALREADY available to the underserved population

Minimum: My institution counts its activities as positive social impact only when it addresses MULTIPLE and INTERSECTING challenges faced by its clients (please respond with your answer to question 8 in mind)

Sustainable: When addressing intersectionality of challenges only those with multiple challenges AND that meet no harm criteria qualify as social impact

Minimum: My institution ONLY counts its activities as positive social impact if it finances SMEs that create or protect jobs

Please define what no significant harm means for your institution when applied to SMEs

Minimum: My institution counts its activities as positive social impact ONLY if its clients provide services to underserved populations (answer for one option only):

ONLY counts its activities as positive social impact if it finances SMEs that create or protect jobs AND do not significantly
harm the environment

\begin{tabular}{l|r} 
Transformative: My institution ONLY counts its activities as positive social impact if its clients are transforming their business activities to sustainably \\
deliver social impact AND do not significantly harm to the environment
\end{tabular} 
49. If my institution is no longer active in the market, the following stakeholders would be negatively impacted

\begin{tabular}{cc}
\hline Individuals in my community & Negatively \\
\hline Enterprises in my community & \\
\hline Other financial institutions & \\
\hline NGOs in my community & \\
\hline Local government actors & \\
\hline Other & Other (please specify) \\
\hline
\end{tabular}

50. Please describe what elements informed your response to question 49

Before you go, please tell us a little bit about yourself and your institution. Thank you once again for your support and for your valuable inputs.

51. Your name

52. Your role

53. Your email

54. Your institution's name

55. Your institution's mission

56. How many employees work in your bank?
a. below 50
b. $\quad 50-99$
c. $100-249$
d. over 250

57. Regions of operation (please list countries, states or cities as appropriate)

58. Looking at your institution's efforts and intentions during the last 3 years, please rank order from most (1) to least (4) efforts and intentions allocated:

\begin{tabular}{llll}
\hline Category & Rank Order \\
\hline Financial returns for investors & - \\
\hline Economic resiliency for clients and communities & - \\
\hline Environmental regeneration for clients and communities & - \\
\hline Social empowerment for clients and communities & - \\
\hline Other & - \\
\hline
\end{tabular}

59. If you selected "Other' in the previous question, please explain:

60. To the best of my knowledge, my institution's business practises and product offerings are in compliance with regulations and norms that protect (please select all that apply):

\begin{tabular}{|c|c|}
\hline 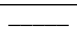 & Human rights \\
\hline 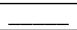 & Labour rights \\
\hline $\bar{\square}$ & Customer privacy \\
\hline$\overline{\overline{2}}$ & Data security \\
\hline 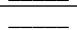 & Access and affordability \\
\hline$\ldots$ & Selling practises and product labelling \\
\hline 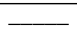 & Employee engagement, diversity and inclusion (social capital/SASB) \\
\hline 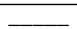 & Product design and lifecycle management \\
\hline$\ldots$ & Physical impacts of climate change \\
\hline $\bar{\square}$ & Systemic risk management \\
\hline 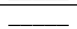 & Business ethics \\
\hline 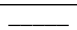 & Other (please specify) \\
\hline
\end{tabular}


61. Looking at your institution's total number of banking services sold as of December 2020, what percent of your core business is accounted by the following banking services (Please provide your best estimate (must add to 100\%))?

\begin{tabular}{c|c}
\hline Banking Services & Percent of Total Number of Banking Services Sold \\
\hline Current accounts & \\
\hline Savings accounts & \\
\hline Microfinance & \\
\hline Consumer loans & \\
\hline Business loans & \\
\hline Mortgages & \\
\hline Investment products & \\
\hline Other & \\
\hline
\end{tabular}

62. If you selected "Other" in the previous question, please explain:

63. If there is anything else you would like to share with us, please enter it here:

\section{Appendix C. CEO Interview Protocol}

Appendix C.1. The VALoRE Project

Overview and Background

The GABV has embarked on a project to inform the work of the European Commission on the EU Taxonomy. With support from the Open Society Foundation, VALoRE will result in a collection of best practises in banking for social impact. This work is of importance more widely as countries embark on efforts to address climate change and transform their economies for a sustainable future.

GABV members finance activities that are socially sustainable and have extensive experience translating social values and objectives into social sustainability and impact on clients and communities.

We have designed an extensive questionnaire to collect best practises by our global community of values-based banks. Your institution has already responded. We thank you for your participation.

In this interview we will expand on your and your institution's approach to social impact. We are particularly interested in understanding how you define, design, implement and monitor social impact. We also want to understand your approach, including tools and instruments, to steering, decision making, and scaling-up social impact. Real-life examples are needed for a better taxonomy. We thank you for agreeing to participate in this interview and for sharing examples of best practises.

\section{Appendix C.2. Why the EU Taxonomy?}

The EU taxonomy is a tool to translate the European Union's long-term goal to reach climate neutrality by 2050. It provides clarity on which economic activities and financial products can be classified as sustainable (inventory for the future). It aspires to be meaningful and relevant to encourage green investments (transition tool). Users of the taxonomy will be able to report consistently and comparably when their products or services are environmentally sustainable (reporting enabler).

Yet, the transition to a low carbon future must be inclusive. The European Commission recognizes the need for socially inclusive measures to accompany the green transition.

\section{Appendix C.3. Interview Protocol}

The interview is scheduled for 60 minutes. The goal of the interview is to explore in detail the following issues:

1. Define and Design: The social impact objectives that you and your institution have, including your target sectors/activities, clients.

2. Implement: Your strategic approach to deliver on these social impact objectives, including how you prioritise and address potential trade-offs, and your business processes and oversight. 
3. Monitor: Your performance, including criteria, assessment and reporting.

\section{Appendix C.4. Selected Questions for CEOs}

The focus of this work is on social sustainability and impact approaches. Please approach the following questions with this in mind:

1. What is the dream you and your institution have for your clients and communities? Please note if this dream is in response to the challenges your clients and communities face, and/or opportunities in your market.

2. How does your bank help achieve that dream? Please provide 2-3 concrete examples. These may include business practises you have put in place, the tools you rely upon to make decisions, how you address trade-offs and whom do you partner with.

3. What values inform your decisions? How do you translate these values into actual and measurable outcomes?

4. How do you know you are doing very well or very little? How far down your supply chain do you investigate to assess your impact? That is, do you examine your clients' role in, for example, helping others to fulfil basic human needs, including the availability, accessibility, acceptability and quality of water and food, healthcare, housing and education?

5. What information do you rely upon to decide to scale-up your impact? How do you address barriers?

\section{Appendix C.5. Background Reading}

Your institution's responses to the GABV questionnaire to collect best practises in banking for social impact.

\section{Appendix C.6. Recording}

We plan to record this interview to facilitate our work to collect best practises. We will only use this information internally. Please let us know if you do not want this interview to be recorded.

\section{References}

1. United Nations Sustainable Goals. Take Action for the Sustainable Development Goals. 2020. Available online: https://www.un. org/sustainabledevelopment/sustainable-development-goals/ (accessed on 26 April 2021).

2. Chen, S.; Ravallion, M. More Relatively-Poor People in a Less Absolutely-Poor World. Policy Research Working Paper 611. 2012. Available online: https:/ / openknowledge.worldbank.org/handle/10986/11876 (accessed on 26 April 2021).

3. Report of the Special Rapporteur on Extreme Poverty and Human Rights. 2016. Available online: https://srpovertyorg.files. wordpress.com/2018/08/social-and-economic-as-human-rights-report-2016.pdf (accessed on 26 April 2021).

4. 2020 Social Progress Index. Available online: https:/ / socialprogress.blog/2020/09/10/announcing-the-2020-social-progressindex/ (accessed on 26 April 2021).

5. Piketty, T. Capital in the Twenty-First Century; The Belknap Press of Harvard University Press: Cambridge, MA, USA, 2014.

6. United Nations Sustainable Development. The Sustainable Development Agenda. Available online: https://www.un.org/ sustainabledevelopment/development-agenda/ (accessed on 5 July 2021).

7. United Nations Environment Programme Finance Initiative. UNEP FI: Principles for Responsible Banking; Guidance Document; UNEP Finance Initiative: Geneva, Switezerland, 2020. Available online: https://www.unepfi.org/wordpress/wp-content/ uploads/2020/12/PRB-Reporting-Guidance-Document.pdf (accessed on 23 April 2021).

8. Fatemi, A.M.; Fooladi, I.J. Sustainable Finance: A New Paradigm. Glob. Financ. J. 2013, 24, 101-113. [CrossRef]

9. Zingales, L.; Kasperkevic, J.; Schechter, A. Milton Friedman 50 Years Later; Stigler Center: Chicago, IL, USA, 2020.

10. Aspinall, N.G.; Jones, S.R.; McNeill, E.H.; Werner, R.A.; Zalk, T. Sustainability and the Financial System Review of Literature 2015. Br. Actuar. J. 2018, 23. [CrossRef]

11. Carolina Rezende de Carvalho Ferrei, M.; Amorim Sobreiro, V.; Kimura, H.; Luiz de Moraes Barboza, F. A Systematic Review of Literature about Finance and Sustainability. J. Sustain. Financ. Investig. 2016, 6, 112-147. [CrossRef]

12. KKS Advisors. Do Sustainable Banks Outperform? Driving Value Creation through ESG Practices. 2019. Available online: http:/ / www.gabv.org/wp-content/uploads/Do-sustainable-banks-outperform.pdf (accessed on 3 May 2021).

13. Pisano, U.; Martinuzzi, A.; Bruckner, B. The Financial Sector and Sustainable Development: Logics, Principles and Actors; EDSN: Vienna, Austria, 2012. 
14. Fullwiler, S.T. Sustainable Finance: Building a More General Theory of Finance. Global Institute for Sustainable Prosperity Working Paper No. 106. 2015. Available online: http://www.global-isp.org/wp-content/uploads/WP-106.pdf (accessed on 26 April 2021).

15. United Nation. Report on the World Social Situation. Bureau of Social Affairs, Social Development; Department for Economic, Social Information, \& Policy Analysis, United Nations: New York, NY, USA, 2016.

16. Dugarova, E. Social Inclusion, Poverty Eradication and the 2030 Agenda for Sustainable Development (No. 2015-15); UNRISD Working Paper; UNRISD: Geneva, Switzerland, 2015. Available online: https:/ /www.unrisd.org/unrisd/website/document.nsf/ (httpPublications)/0E9547327B7941D6C1257EDF003E74EB?OpenDocument (accessed on 26 April 2021).

17. Ozili, P.K. Social Inclusion and Financial Inclusion: International Evidence. Int. J. Dev. Issues 2020, 19. [CrossRef]

18. Chibba, M. Financial inclusion, poverty reduction and the millennium development goals. Eur. J. Dev. Res. 2009, 21, 213-230. [CrossRef]

19. Kandpal, V. Reaching sustainable development goals: Bringing financial inclusion to reality in India. J. Public Aff. 2020, 20, e2277. [CrossRef]

20. Robinson, J.; Dupas, P. Constraints to Saving for Health Expenditures in Kenya. 2011. Available online: https://www. povertyactionlab.org/evaluation/constraints-saving-health-expenditures-kenya (accessed on 3 May 2021).

21. Brune, L.; Giné, X.; Goldberg, J.; Yang, D. Facilitating savings for agriculture: Field experimental evidence from Malawi. Econ. Dev. Cult. Chang. 2016, 64, 187-220. [CrossRef]

22. European Commission. Sustainable Finance Action Plan. Available online: https://ec.europa.eu/info/business-economy-euro/ banking-and-finance/sustainable-finance_en (accessed on 26 April 2021).

23. Schoenmaker, D. Investing For The Common Good: A Sustainable Finance Framework; Bruegel: Brussels, Belguim, 2017.

24. Ziolo, M.; Filipiak, B.Z.; Bąk, I.; Cheba, K.; Tîrca, D.M.; Novo-Corti, I. Finance, Sustainability and Negative Externalities. An Overview of the European Context. Sustainability 2019, 11, 4249. [CrossRef]

25. United Nations Environment Programme Finance Initiative. Rethinking Impact to Finance the SDGs. A Position Paper and Call to Action Prepared by the Positive Impact Initiative. 2018. Available online: https:/ /www.unepfi.org/wordpress/wp-content/ uploads/2018/11/Rethinking-Impact-to-Finance-the-SDGs.pdf (accessed on 26 April 2021).

26. Nizam, E.; Ng, A.; Dewandaru, G.; Nagayev, R.; Nkoba, M.A. The impact of social and environmental sustainability on financial performance-A global analysis of the banking sector. J. Multinatl. Financ. Manag. 2020, 49, 35-53. [CrossRef]

27. Khan, M.; Serafeim, G.; Yoon, A. Corporate Sustainability: First Evidence on Materiality. Acc. Rev. 2016, 91, 1697-1724. [CrossRef]

28. United Nations Environment Programme Finance Initiative. The Principles for Positive Impact Finance. A Common Framework to Finance the Sustainable Development Goals. 2017. Available online: https://www.unepfi.org/wordpress/wp-content/ uploads/2017/01/POSITIVE-IMPACT-PRINCIPLES-AW-WEB.pdf (accessed on 26 April 2021).

29. EU Technical Expert Group on Sustainable Finance. Taxonomy Technical Report. Financing a Sustainable European Economy. 2019. Available online: https://ec.europa.eu/info/sites/default/files/business_economy_euro/banking_and_finance/ documents /190618-sustainable-finance-teg-report-taxonomy_en.pdf (accessed on 3 May 2021).

30. Nedopil Wang, C.; Lund Larsen, M.; Wang, Y. Addressing the Missing Linkage in Sustainable Finance: The 'SDG Finance Taxonomy'. J. Sustain. Financ. Investig. 2020. [CrossRef]

31. Batista, J.; Boonstra, J. Leadership and Organizational Culture Based on Sustainable Innovational Values: Portraying the Case of the Global Alliance for Banking Based on Values (GABV). ESADE Business School Working Paper No. 270. 2018. Available online: https:/ /www.sioo.nl/wp-content/uploads/2019/05/Leadership_and_organizational_culture_based_on_sustainable_ innovational_values.pdf (accessed on 3 May 2021).

32. Nosratabadi, S.; Pinter, G.; Mosavi, A.; Semperger, S. Sustainable Banking, Evaluation of the European Business Models. Sustainability 2020, 12, 2314. [CrossRef]

33. Emerson, J.; Cabaj, M. Social Return on Investment. Mak. Waves 2000, 11. Available online: https://auspace.athabascau.ca/ bitstream/handle/2149/1028/MW110210.pdf?sequence=1\&isAllowed=y (accessed on 3 May 2021).

34. Clark, C.; Rosenzweig, W.; Long, D.; Olsen, S. Double Bottom Line Project Report: Assessing Social Impact in Double Bottom Line Ventures. Working Paper, 13. 2004. Available online: https:/ / community-wealth.org/sites/clone.community-wealth.org/ files/downloads/paper-rosenzweig.pdf (accessed on 3 May 2021).

35. Maas, K.; Liket, K. Social Impact Measurement: Classification of Methods. In Environmental Management Accounting and Supply Chain Management; Springer: Berlin/Heidelberg, Germany, 2011.

36. Burdge, R.J.; Vanclay, F. Social Impact Assessment: A Contribution to the State of the Art Series. Impact Assess. 1996, 14. [CrossRef]

37. Gentile, M. Social Impact Management: A Definition, Business and Society program. The Aspen Institute Business and Society Program Discussion Paper No. 11. 2002. Available online: https://www.aspeninstitute.org/wp-content/uploads/files/content/ docs/bsp/SOCIALIMPACTMANAGEMENT.PDF (accessed on 23 April 2021).

38. Vanclay, F. International Principles For Social Impact Assessment. Impact Assess. Proj. Apprais. 2003, 21. [CrossRef]

39. United Nations Environment Programme Finance Initiative. Positive Impact Finance. A Common Vision for the Financing of the Sustainable Development Goals (SDGs), Brussels, 2015. Available online: https:/ /www.unepfi.org/wordpress/wp-content/ uploads/2017/01/POSITIVE-IMPACT-MANIFESTO-NEW-1.pdf (accessed on 3 May 2021).

40. Global Alliance for Banking on Values. What Are Principles of Values-Based Banking? Available online: https://www.gabv.org/ wp-content/uploads/Prinicples-of-Values-based-Banking.pdf (accessed on 8 April 2021). 
41. Migliorelli, M. What Do We Mean by Sustainable Finance? Assessing Existing Frameworks and Policy Risks. Sustainability 2021, 13, 975. [CrossRef]

42. UNEP FI. The Impact Radar: A Tool for Holistic Impact Analysis, Brussels, 2018. Available online: https://www.unepfi.org/ wordpress/wp-content/uploads/2018/11/PI-Impact-Radar.pdf (accessed on 3 April 2021).

43. De Clerck, F. Ethical Banking. In Ethical Prospects; Zsolnai, L., Boda, Z., Fekete, L., Eds.; Springer: Dordrecht, The Netherlands, 2009; Volume 1.

44. Carè, R. Sustainable Banking; Springer International Publishing: Cham, Switzerland, 2018.

45. Nakano, Y.; Magezi, E.F. The Impact of Microcredit on Agricultural Technology Adoption and Productivity: Evidence from Randomized Control Trial in Tanzania. World Dev. 2020, 133, 104997. [CrossRef]

46. Agyemang, S.A.; Ratinger, T.; Ahado, S. Has Microcredit Boosted Poultry Production in Ghana? Agric. Financ. Rev. 2019, 80. [CrossRef]

47. Imeson, M.; Sim, A. Sustainable Banking: Why Helping Communities and Saving the Planet Is Good for Business? SAS White Paper; SAS Institute Inc.: San Diego, CA, USA, 2010.

48. Stankeviciene, J.; Nikonorova, M. Sustainable Value Creation in Commercial Banks During Financial Crisis. Procedia Soc. Behav. Sci. 2014, 110, 1197-1208. [CrossRef]

49. Weber, O.; Feltmate, B. Sustainable Banking; University of Toronto Press: Toronto, ON, Canada, 2016.

50. Abad Segura, E.; del Carmen Valls Martínez, M. Análisis Estratégico de La Banca Ética En España a Través de Triodos Bank. Financiación de Proyectos Sociales y Medioambientales. CIRIEC-España, Revista de Economía Pública, Social y Cooperativa 2018, No. 92. Available online: https:/ / ojs.uv.es/index.php/ciriecespana/article/view/10805 (accessed on 15 April 2021).

51. Chew, B.C.; Tan, L.H.; Hamid, S.R. Ethical Banking in Practice: A Closer Look at the Co-Operative Bank UK PLC. Qual. Res. Financ. Mark. 2016, 8. [CrossRef]

52. Tan, L.; Chew, B.; Hamid, S. A Holistic Perspective on Sustainable Banking Operating System Drivers: A Case Study of Maybank Group. Qual. Res. Financ. Mark. 2017, 9, 240-262. [CrossRef]

53. The Charity Bank Limited. Measuring Social Impact: Our Approach. A Brief Guide to How and Why We Measure Social Impact; Charity Bank: Tonbridge, UK, 2015. Available online: https:/ / charitybank.org/uploads/files/Social-Impact-Statement-2015.pdf (accessed on 3 May 2021).

54. Epstein, M.; Buhovac, A. Making Sustainability Work: Best Practices in Managing and Measuring Corporate Social, Environmental, and Economic Impacts; Greenleaf Publishing Limited: Sheffield, UK, 2014.

55. Burritt, R.L.; Hahn, T.; Schaltegger, S. Towards a Comprehensive Framework for Environmental Management Accounting-Links between Business Actors and Environmental Management Accounting Tools. Aust. Acc. Rev. 2002, 12. [CrossRef]

56. Becchetti, L.; Garcia, M.M.; Trovato, G. Credit Rationing and Credit View: Empirical Evidence from an Ethical Bank in Italy. J. Money Credit Bank. 2011, 43. [CrossRef]

57. Pedrini, M.; Langella, V.; Bramanti, V. Review of Impact Assessment Methodologies for Ethical Finance. 2015. Available online: https:/ / www.socioeco.org/bdf_fiche-document-3714_en.html (accessed on 3 May 2021).

58. Bonini, S.; Emerson, J. Maximizing Blended Value-Building beyond the Blended Value Map to Sustainable Investing, Philanthropy and Organizations. Available online: https:/ /staging.community-wealth.org/sites/clone.community-wealth.org/files/ downloads/report-bonini3.pdf (accessed on 3 May 2021).

59. Antony, J.; Gupta, S. Top Ten Reasons for Process Improvement Project Failures. Int. J. Lean Six Sigma 2019, 10. [CrossRef]

60. Pinto, J.K.; Prescott, J.E. Variations in Critical Success Factors Over the Stages in the Project Life Cycle. J. Manag. 1988, 14. [CrossRef]

61. Chapman, C.; Ward, S. Project Risk Management, 2nd ed.; John Wiley and Sons Ltd.: Hoboken, NJ, USA, 2003.

62. Barberá, L.; Crespo, A.; Viveros, P.; Stegmaier, R. Advanced Model for Maintenance Management in a Continuous Improvement Cycle: Integration into the Business Strategy. Int. J. Syst. Assur. Eng. Manag. 2012, 3, 47-63. [CrossRef]

63. Gatchalian, M.M. People Empowerment: The Key to TQM Success. TQM Magazine, 1 December 1997. [CrossRef]

64. Khan, S.A.; Kaviani, M.A.; Galli, B.J.; Ishtiaq, P. Application of Continuous Improvement Techniques to Improve Organization Performance. Int. J. Lean Six Sigma 2019, 10. [CrossRef]

65. van Assen, M.F. Empowering Leadership and Contextual Ambidexterity-The Mediating Role of Committed Leadership for Continuous Improvement. Eur. Manag. J. 2020, 38. [CrossRef]

66. Hollweck, T. Robert K. Yin. (2014). Case Study Research Design And Methods (5th Ed.). Thousand Oaks, CA: Sage. 282 Pages. Can. J. Progr. Eval. 2016.

67. Patton, M.Q. Two Decades of Developments in Qualitative Inquiry. Qual. Soc. Work 2002, 1. [CrossRef]

68. Weber, O. Social Banking: Concept, Definitions and Practice. Glob. Soc. Policy 2014, 14. [CrossRef]

69. Boonstra, J. Managing Strategic and Cultural Change in Organizations. J. Financ. Transform. 2021, 52, 112-121.

70. Global Alliance for Banking on Values. Real Economy-Real Returns: The Business Case for Values-Based Banking. 2020. Available online: https:/ / www.gabv.org/news/real-economy-real-returns-the-business-case-for-values-based-banking (accessed on 26 April 2021).

71. Schäfer, T.; Utz, S. Values-Based and Global Systemically Important Banks: Their Stability and the Impact of Regulatory Changes after the Financial Crisis on It. Asia-Pac. Financ. Mark. 2021. [CrossRef]

72. DeVellis, R. Scale Development: Theory and Applications; Sage Publications: Thousand Oaks, CA, USA, 1991. 
73. Creswell, J.; Plano Clark, V. Designing and Conducting Mixed Methods Research, 2nd ed.; SAGE Publications: Thousand Oaks, CA, USA, 2010.

74. Thomas, D.R. A General Inductive Approach for Analyzing Qualitative Evaluation Data. Am. J. Eval. 2006, 27. [CrossRef]

75. San-Jose, L.; Retolaza, J.L.; Gutierrez-Goiria, J. Are Ethical Banks Different? A Comparative Analysis Using the Radical Affinity Index. J. Bus. Ethics 2011, 100, 151-173. [CrossRef]

76. Triodos Bank. Annual Report 2017. Available online: https://www.triodos.com/binaries/content/assets/tbho/annual-figures/ triodos-bank-annual-report-2017.pdf (accessed on 15 April 2021).

77. Kay, J. Other People's Money; Profile Books Ltd.: London, UK, 2016.

78. World Benchmarking Alliance. Financial System Transformation Scoping Report. 2021. Available online: https://assets. worldbenchmarkingalliance.org/app/uploads /2021/01/WBA-Financial-System-Transformation-Scoping-Report-January-20 21-WEB.pdf (accessed on 15 April 2021).

79. Impact Institute. Impact Measurement and Valuation for Banks. Available online: https://www.impactinstitute.com/impactmeasurement-and-valuation-for-banks/ (accessed on 3 May 2021).

80. Deeper and Fairer Economic and Monetary Union, European Commission. Available online: https://ec.europa.eu/commission/ priorities / deeper-and-fairer-economic-and-monetary-union/european-pillar-social-rights/european-pillar-social-rights-20 -principles_en (accessed on 26 April 2021).

81. Bank Australia. Our Responsible Banking Policy. Available online: https://www.bankaust.com.au/globalassets/assets/ reporting-governance--policies/policies-plans--positions / responsible-banking-policy/responsible-banking-policy-statement. pdf (accessed on 15 April 2021).

82. Scott, J.M.; Hussain, J. Exploring Intersectionality Issues in Entrepreneurial Finance: Policy Responses and Future Research Directions. Strateg. Chang. 2019, 28,37-45. [CrossRef]

83. Kalsem, K. Bankruptcy Reform and the Financial Well Being of Women: How Intersectionality Matters in Money Matters. Brooklyn Law Rev. 2006, 71, 1181.

84. Costanza-Chock, S. Design Justice: Towards an intersectional feminist framework for design theory and practice. In Proceedings of the DRS International Conference-Design as a Catalyst for Change, Limerick, Ireland, 25-28 June 2018. [CrossRef]

85. Lurie, K.; Schuster, B.; Rankin, S. Discrimination at the Margins: The Intersectionality of Homelessness \& Other Marginalized Groups. SSRN Electron. J. 2015. [CrossRef]

86. Crenshaw, K. Demarginalizing the Intersection of Race and Sex: A Black Feminist Critique of Antidiscrimination Doctrine, Feminist Theory and Antiracist Politics. Univ. Chic. Leg. Forum 1989, 1, $139-167$.

87. GABV's COVID-19 Resource Hub. GABV Members Responses to the Coronavirus. Available online: https://www.gabv.org/ covid-19-resource-hub (accessed on 29 April 2021).

88. GLS Bank. Anlage und Finanzierungsgrundsätze. Available online: https://www.gls.de/media/PDF/Broschueren/GLS_Bank/ gls_anlage-und_finanzierungsgrundsaetze.pdf (accessed on 29 April 2021).

89. Beneficial State. Mission Principles and Policies. Available online: https://impact.beneficialstate.org/mission-principles-andpolicies / (accessed on 29 April 2021).

90. Triodos Bank. Minimum Standards. 2018. Available online: https://www.triodos.com/downloads/about-triodos-bank/triodosbanks-minimum-standards.pdf (accessed on 8 April 2021).

91. Triodos Bank. Business Principles. 2016. Available online: https://www.triodos.com/binaries/content/assets/tbho/corporategovernance/triodos-bank-business-principles.pdf (accessed on 3 May 2021).

92. NRB News. NRB Releases Monetary Policy for FY 2020-21. Publication of the Central Bank of Nepal. Volume 41. Available online: https:/ / www.nrb.org.np/contents/uploads/2020/12/NRB-News-Vol.40-20770818.pdf (accessed on 15 April 2021).

93. Reporte di Impatto 2020. Insieme, Facciamo Crescere una Nuova Economia, Banca Etica, 2020. Available online: https: // bancaetica.it/report-impatto-2019/pdf/Report_impatto_ITA.pdf (accessed on 26 April 2021). 